\title{
Adsorptive removal of heavy metals from water using sodium titanate nanofibres loaded onto GAC in fixed-bed columns
}

D. P. Sounthararajah, P. Loganathan, J. Kandasamy, S. Vigneswaran*

Faculty of Engineering and Information Technology, University of Technology Sydney, Broadway, NSW 2007, Australia.

*corresponding author: S. Vigneswaran, Faculty of Engineering and Information Technology, University of Technology Sydney, Broadway, NSW 2007, Australia.

E-mail: s.vigneswaran@uts.edu.au

Phone: +61 295142641

Fax: $\quad+61295142633$

\section{Highlights}

Sodium titanate nanofibres(TNF) had high adsorption capacity for heavy metals

Metal removals in column with 4\% TNF + 96\% GAC were larger than in 100\% GAC

TNF batch/column adsorption from single/mixed metals systems $\mathrm{Pb}>\mathrm{Cu}, \mathrm{Cd}>\mathrm{Zn}>\mathrm{Ni}$

$\mathrm{Ni}$ and $\mathrm{Zn}$ adsorption in mixed metals solution decreased at high metals concentration

\section{Statement of significance}

Novelty of this study is the simultaneous removal of five heavy metals by a novel nanomaterial having high adsorption capacities for these metals in fixed-bed columns as practiced in water treatment plants by using a blend of small proportion of this nanomaterial with a commonly used adsorbent and providing an explanation of the metals removal mechanism. 


\begin{abstract}
Heavy metals are serious pollutants in aquatic environments. A study was undertaken to remove $\mathrm{Cu}$, $\mathrm{Cd}, \mathrm{Ni}, \mathrm{Pb}$ and $\mathrm{Zn}$ individually (single metal system) and together (mixed metals system) from water by adsorption onto a sodium titanate nanofibrous material. Langmuir adsorption capacities (mg/g) at $10^{-3} \mathrm{M} \mathrm{NaNO}_{3}$ ionic strength in the single metal system were 60, 83, 115 and 149 for $\mathrm{Ni}, \mathrm{Zn}, \mathrm{Cu}$, and $\mathrm{Cd}$, respectively, at $\mathrm{pH} 6.5$ and 250 for $\mathrm{Pb}$ at $\mathrm{pH}$ 4.0. In the mixed metals system they decreased at high metals concentrations. In column experiments with 4\% titanate material and 96\% granular activated carbon (w/w) mixture at $\mathrm{pH} 5.0$, the metals breakthrough times and adsorption capacities (for both single and mixed metals systems) decreased in the order $\mathrm{Pb}>\mathrm{Cd}, \mathrm{Cu}>\mathrm{Zn}>\mathrm{Ni}$ within 266 bed volumes. The amounts adsorbed were up to 82 times higher depending on the metal in the granular activated carbon + titanate column than in the granular activated carbon column. The study showed that the titanate material has high potential for removing heavy metals from polluted water when used with granular activated carbon at a very low proportion in fixed-bed columns.
\end{abstract}

Keywords: adsorption, granular activated carbon, heavy metals, titanate nanofibres,

\title{
1. Introduction
}

The ever-increasing pollutant levels in water are a serious global environmental problem. Heavy metals constitute major pollutants that are generating much concern due to their acute toxicity, long-term accumulation and persistence. Numerous methods are available for removing heavy metals from contaminated water such as chemical precipitation, ion exchange adsorption, membrane filtration and electrochemical technologies [1-3]. Of these methods, adsorption is preferred for its simplicity, efficiency, flexibility in design and low waste production [3-5].

In the adsorbent group, nano-sized metal oxides are growing in importance due to their unique properties and use in many applications. Nano-sized metal oxides have promising metal removal capacities, partly due to their large surface areas and high activities in size-quantisation effect $[6,7]$. However, these nano-sized particles are unusable as they are in fixed-bed columns where they cause excessive pressure drop and have poor mechanical strength $[4,5,8]$. To overcome this problem, nano-sized particles are commonly impregnated into coarse-sized porous material such as granular activated carbon (GAC) [9-12] and used in fixed-bed columns.

Titanium-based adsorbents show robustness under harsh chemical conditions and are effective in a variety of media such as acidic, basic and neutral $\mathrm{pH}$ and high and low ionic strengths [2]. Mesoporous titanate nanostructures have been synthesised from $\mathrm{TiO}_{2}$ using a variety of technologies and used to remove pollutants including heavy metals [2,13,14]. For example, Hang et al. [15] reported that titanate whiskers prepared using an alkaline hydrothermal method starting from 
hydrous metatitanic acid and $\mathrm{KOH}$ had a Langmuir maximum adsorption capacity of 144 and 385 $\mathrm{mg} / \mathrm{g}$ for $\mathrm{Cu}$ and $\mathrm{Pb}$, repectively in a batch study. Sheng and $\mathrm{Hu}$ [16] found that titanate nanotubes prepared using a similar hydrothermal method with titanium oxide and $\mathrm{NaOH}$ had a Langmuir adsorption capacity of $51 \mathrm{mg} / \mathrm{g}$ for Th(IV). However, simultaneous removal of several heavy metals from their mixtures in both batch $[17,18]$ and column adsorption conditions is rare. The simultaneous removal of several heavy metals is important as most wastewaters contain more than one heavy metal and there can be competition for adsorption between metals.

This study aimed to determine the adsorptive removal efficiencies of five heavy metals $(\mathrm{Cu}$, $\mathrm{Zn}, \mathrm{Pb}, \mathrm{Cd}$ and $\mathrm{Ni}$ ) individually and together from synthetically polluted water using a sodium titanate nanofibrous material (TNF) in batch experiments and mixed with a wood-based GAC in fixed-bed column experiments.

\section{Experimental methodology}

\subsection{Preparation of TNF}

A commercial titanium dioxide (P-25, Degussa AG, Germany) was used as a precursor for preparing the sodium form of titanate microspheres (TNF). P-25 is a non-porous, crystalline structure with $70 \%$ anatase, $30 \%$ rutile composition and a BET surface area of $50 \mathrm{~m}^{2} / \mathrm{g}$ with a mean particle size of about $30 \mathrm{~nm}$ [14]. TNF was prepared using a modified hydrothermal method similar to that described by El Saliby et al. [14]. In this method, $12 \mathrm{~g}$ of $\mathrm{NaOH}$ pellets were weighed into a Teflon cell containing $6 \mathrm{~g}$ of the $\mathrm{TiO}_{2}$ powder. To this container which was kept in a water bath at room temperature $\left(24 \pm 1^{\circ} \mathrm{C}\right), 36 \mathrm{ml}$ of $\mathrm{H}_{2} \mathrm{O}_{2}(50 \% \mathrm{~V} / \mathrm{V})$ was added drop-wise and the mixture was mechanically stirred for $5 \mathrm{~min}$ at $300 \mathrm{rpm}$. The resultant slurry was kept in a water bath for $24 \mathrm{~h}$ at $80^{\circ} \mathrm{C}$ without any vigorous agitation. The precipitate obtained was washed repeatedly with Milli Q water, $\mathrm{pH}$ neutralised to 7.0 using $2 \mathrm{~N} \mathrm{HCl}$, and dried at $100^{\circ} \mathrm{C}$. The resultant nanotitanate had a pale yellow colour characteristic of peroxotitanate materials precipitated under alkaline conditions [2].

\subsection{GAC}

A wood-based granular activated carbon (GAC) obtained from James Cummins P/L, Australia was sieved to a particle size range of 0.3-0.6 mm and used in the study. The GAC had a BET surface area of $950 \mathrm{~m}^{2} / \mathrm{g}$.

\subsection{Characterisation of TNF}


X-ray diffraction (XRD) was conducted using a XRD Shimadzu S6000 (Japan) diffractometer on powder samples of TNF. The X-ray diffraction unit (Theta/2Theta) was equipped with a Cu target operated at $40 \mathrm{kV}$ and $30 \mathrm{~mA}$ with a setting of 5-45 2-theta, step time $2^{\circ} 1 / \mathrm{min}$. Scanning electron microscopy (SEM), Fourier transform infrared (FT-IR) spectroscopy, surface area, and porosity measurements were also conducted on TNF. For the SEM analysis, samples were imaged, uncoated, in a Zeiss Evo LS15 SEM using its variable pressure mode and an accelerating voltage of $15 \mathrm{kV}$. FTIR pattern was recorded in a Nicolet 6700 FTIR Spectrometer equipped with a room temperature DLaTGS detector and a Nicolet FT-IR Smart System with Smart Accessories using a Diamond crystal HATR. Surface area and porosity were determined by nitrogen-sorption measurements carried out at $77 \mathrm{~K}$ with a Micromeritics 3Flex surface characterisation analyser.

\subsection{Zeta potential}

Zeta potential which is linked to the surface charge was measured at different pHs on GAC and TNF suspensions using a zetasizer nano instrument (Nano ZS Zne 3600, Malvern, UK). For each sample, the instrument automatically made triplicate measurements and a mean value was produced. Zeta potential was measured at $\mathrm{pH} 3$ to 9, after adjusting the $\mathrm{pH}$ of $100 \mathrm{ml}$ suspension of TNF in deionised water with background ionic strength of $10^{-3} \mathrm{M} \mathrm{NaNO}_{3}(0.5 \mathrm{~g} / \mathrm{L}$ dose of TNF) and agitating it at $120 \mathrm{rpm}$ for $24 \mathrm{~h}$.

\subsection{Batch adsorption experiments}

For the laboratory batch experiments, Milli Q water was spiked with individual heavy metals $(\mathrm{Cu}, \mathrm{Zn}, \mathrm{Pb}, \mathrm{Cd}$, and $\mathrm{Ni}$ ) using their nitrate salts at a concentration of $5 \mathrm{mg} / \mathrm{L}$. Different doses of TNF ( 0.01 to $0.09 \mathrm{~g} / \mathrm{L}$ ) were added to $100 \mathrm{ml}$ of these metal solutions, and the suspensions were agitated at $120 \mathrm{rpm}$ for $24 \mathrm{~h}$ at room temperature $\left(24 \pm 1^{\circ} \mathrm{C}\right)$ and different suspension pHs. The background ionic strength was kept at $10^{-3} \mathrm{M} \mathrm{NaNO}_{3}$. After $2 \mathrm{~h}$ of agitating the suspensions, $\mathrm{pH}$ was adjusted back to the initial $\mathrm{pH}$ using $0.1 \mathrm{M} \mathrm{NaOH}$ or $0.1 \mathrm{M} \mathrm{HNO}_{3}$, in order to eliminate the possibility of any major $\mathrm{pH}$ changes during adsorption. Buffered solutions were not used to keep the $\mathrm{pH}$ constant because the buffer components may have interfered with metals adsorption by forming metals complexes and competing with metals for adsorption. After a further $20 \mathrm{~h}$ of agitation the suspensions were filtered using filter disks with $1.2 \mu \mathrm{m}$ openings and heavy metal concentrations in the filtrate were analysed using a Microwave Plasma-Atomic Emission Spectrometer (Agilent 4100 MP-AES). The experiments were repeated utilising a mixture of heavy metals with a concentration of $15 \mathrm{mg} / \mathrm{L}$ each and TNF doses of 0.05-0.5 g/L. The amount of heavy metal adsorption at equilibrium, $\mathrm{Q}_{\mathrm{e}}(\mathrm{mg} / \mathrm{g})$, was calculated using equation (1): 
$Q_{e}=\frac{\left(\mathrm{C}_{0}-\mathrm{C}_{e}\right) \mathrm{V}}{\mathrm{M}}$

Where, $\mathrm{C}_{0}=$ initial concentration of the heavy metal $(\mathrm{mg} / \mathrm{L}) ; \mathrm{C}_{\mathrm{e}}=$ equilibrium concentration of the heavy metal (mg/L); V = volume of the solution (L); and M = mass of TNF (g).

\subsection{Batch desorption and TNF regeneration experiment}

To use an absorbent economically and effectively it should be reutilized many times. This requires complete desorption of the previously adsorbed metals and regeneration of the adsorbent to its original adsorption capacity. An experiment was conducted where $\mathrm{Ni}, \mathrm{Zn}, \mathrm{Cd}, \mathrm{Cu}$, and $\mathrm{Pb}$ were adsorbed by $2 \mathrm{~g}$ TNF from a $1.5 \mathrm{~L}$ solution containing $20 \mathrm{mg} / \mathrm{L}$ of each metal at $\mathrm{pH}$ 5.0, after shaking the suspensions for $3 \mathrm{~h}$ and filtering these suspensions. The adsorbed metals were desorbed by shaking the residues with $1.5 \mathrm{~L}$ of $0.1 \mathrm{M} \mathrm{NaNO}_{3}$, or $0.1 \mathrm{M} \mathrm{HNO}_{3}$ for $3 \mathrm{~h}$. $0.1 \mathrm{M} \mathrm{NaNO}_{3}$ was selected because it provided large amounts of a cation that could displace the adsorbed metals. $0.1 \mathrm{M} \mathrm{HNO}_{3}$ was chosen to produce low pH where the adsorption of metals is low (Fig. 4). Following the metals' desorption the TNF was again tested for its adsorption capacity. A portion of the TNF, after desorption with $0.1 \mathrm{M} \mathrm{HNO}_{3}$, was treated with $0.2 \mathrm{M} \mathrm{NaOH}$ for $3 \mathrm{~h}$ to introduce the lost $\mathrm{Na}$ into the TNF structure [19] and the adsorption of metals was resumed.

\section{7. $\quad$ Fixed-bed column experiments}

Using TNF alone as the filter media to remove heavy metals from water in the fixed-bed column is not practical because it causes poor hydraulic conductivity giving rise to large head loss. Therefore a mixture of TNF (75-150 $\mu \mathrm{m})$ and GAC (0.3-0.6 mm), a material commonly used in fixedbed columns to remove pollutants, at a weight ratio of 25:1 (GAC: TNF) was used in this study. To determine the effect of TNF alone, two columns - one with GAC alone and the other with GAC + TNF - were used. TNF's removal of heavy metals was calculated by subtracting the amounts of heavy metals removed by GAC from those removed by GAC + TNF.

The GAC used was initially washed thoroughly with deionised water to remove any fine and floating particles. Then 39g of the washed GAC or 37.5g GAC + 1.5g TNF was packed into a $2 \mathrm{~cm}$ internal diameter transparent acrylic fibre column to $30 \mathrm{~cm}$ height. Tap water at $\mathrm{pH} 5.0$ was passed through the column in a gravity flow mode at a velocity of $5 \mathrm{~m} / \mathrm{h}$ for $24 \mathrm{~h}$ to eliminate the $\mathrm{pH}$ increase normally expected when using unwashed GAC as an adsorbent [20]. The tap water was spiked with 
heavy metals, one at a time, at a concentration of $5 \mathrm{mg} / \mathrm{L}$ each, at $\mathrm{pH}$ 5.0. Tap water (ionic strength of $95.1 \mathrm{mg} / \mathrm{L}$ ) was utilised instead of distilled water at the ionic strength of $10^{-3} \mathrm{M} \mathrm{NaNO}_{3}$ as in the batch study because large volumes of distilled water that were required for the long-term column study were not available. Concentrations of heavy metals larger than those normally observed in stormwater and wastewater were used to simulate metals concentrations normally observed in the first flush of stormwater after long dry periods [21,22] and in industrial spills in water and wastewater.

Experiments were then conducted by filtrating metals-spiked tap water at a velocity of $5 \mathrm{~m} / \mathrm{h}$ in the gravity flow mode with two peristaltic pumps; one before the water enters the column and the other when the water leaves the column. The empty bed contact time (EBCT) at this filtration velocity was $3.6 \mathrm{~min}$. Samples were collected at $30 \mathrm{~min}$ and thereafter every hour and analysed for $\mathrm{pH}$ and heavy metals concentrations. The experiments were repeated with a mixture of heavy metals with each metal at a concentration of $1 \mathrm{mg} / \mathrm{L}$.

The maximum column adsorption capacity, $\mathrm{q}_{\text {total }}(\mathrm{mg})$ for a given feed concentration is equal to the area under the plot of the adsorbed metal concentration, $C_{a d}\left(C_{a d}=C_{o}-C\right)(m g / L)$ versus time (t, min) and was calculated manually from the breakthrough curves using Microsoft Excel spreadsheet according to equation (2) where $\mathrm{Q}$ is the flow rate of the solution $(\mathrm{L} / \mathrm{min})$ :

$q_{\text {total }}=\frac{Q}{1000} \int_{t=0}^{t=16 h} C_{a d} \mathrm{dt}$

\section{Results and Discussion}

\subsection{Characterisation of TNF}

Scanning electron microscopic images revealed that TNF had a nanofibrous appearance (Supplementary figure SF1) similar to that observed for materials prepared by others using similar methods $[2,23,24]$. The exact appearance of the nanomaterials depends on the duration and temperature of the $\mathrm{NaOH}$ reaction in their preparations. For example, Yada et al. [24] reported that at $20 \mathrm{~h}$ and $100-120^{\circ} \mathrm{C} \mathrm{NaOH}$ reaction conditions, short nanofibres were evident, but when the reaction time was increased to $72 \mathrm{~h}$, a clear long fibrous material was observed.

X-ray diffraction pattern of the TNF sample had peaks corresponding to anatase, rutile and sodium titanate (Fig. 1). The peaks at 2-theta of 25.5, 38 and 48.5 are characteristics of the presence of anatase [14,25]. Those at 2-theta of 27.5 and 63 are characteristic of rutile $[14,26]$ and those of 9.5, 24.5, 28.5 and 48.5 are typical of sodium titanate [26,27-39]. The peak at 48.5 is common for both anatase and sodium titanate as also found by Wang et al. [26]. The anatase and rutile peaks observed in the XRD pattern are those of the unreacted Degussa P-25 used to prepare the nanotitanate material. 
The major peaks observed in the XRD pattern in the current study are the same as those reported for the titanate nanorods, nanoflowers and nanosheets synthesised by the hydrothermal treatment of anatase using $10 \mathrm{M} \mathrm{NaOH}$ [28].

FIG. 1

Four FTIR transmittance bands, centred at 3390, 1635, 1347, and $450 \mathrm{~cm}^{-1}$, similar to those reported for sodium titanate nanofibres [24] and nanotubes [30], were obtained for TNF (Fig. 2). Kubo and Nakahira [31] also reported similar FTIR bands, one at $3400 \mathrm{~cm}^{-1}$ and another at $1630 \mathrm{~cm}^{-1}$ for a nanotubular titanate material and assigned them to $\mathrm{O}-\mathrm{H}$ stretching mode of interlayer water, oxonium ions, and hydroxyl groups, and $\mathrm{H}-\mathrm{O}-\mathrm{H}$ bending of water, respectively. Huang et al. [32] also assigned the $1630 \mathrm{~cm}^{-1}$ band obtained for their titanate nanotubes and nanowires to $\mathrm{H}-\mathrm{O}-\mathrm{H}$ deformation mode. The band at $450 \mathrm{~cm}^{-1}$ is probably due to Ti-O-Ti vibrations in $\mathrm{TiO}_{6}$ octahectrons [30,32]. The band at $1347 \mathrm{~cm}^{-1}$ is probably due to Na-O vibration as reported for a titanate nanotube material prepared by an alkaline hydrothermal method where a band appeared at $1400 \mathrm{~cm}^{-1}$ [30].

FIG. 2

The BET surface area and total pore volume of TNF were $58.6 \mathrm{~m}^{2} / \mathrm{g}$ and $0.142 \mathrm{~cm}^{3} / \mathrm{g}$, respectively. These values are comparable to those of $64.8 \mathrm{~m}^{2} / \mathrm{g}$ and $0.25 \mathrm{~cm}^{3} / \mathrm{g}$, respectively, as reported by El Saliby et al. [14].

The zeta potential data at different $\mathrm{pHs}$ showed that a rise of $\mathrm{pH}$ increased the negative zeta potential of GAC and TNF (Fig. 3). TNF had higher negative zeta potential than GAC at all pHs. The zero point of charge (ZPC, i.e. the pH at which the net surface charge is zero) of TNF and GAC were 3.2 and 5.5, respectively, suggesting that at the normal $\mathrm{pH}$ of 6-7 of most wastewaters the net surface charge on these materials is negative. This favours the adsorption of the positively charged heavy metal cations. The ZPC of 5.5 obtained for GAC is within the range of 4.75-7.00 reported for five types of activated carbons by Faust and Aly [33]. The ZPC of TNF of 3.2 agrees well with the ZPC values of 3.16- 3.55 reported by Chen et al. [30] for sodium titanate nanomaterials.

FIG. 3 


\subsection{Batch adsorption}

\subsection{1. $p H$ effect}

The adsorption of all the heavy metals continued to increase when equilibrium $\mathrm{pH}$ rose from 3 to 7.5 (Fig. 4). There are many reasons for this increased adsorption. Firstly, at low pHs the adsorption is low because there are less negative charges on the TNF surface (Fig. 3) for adsorbing the positively charged heavy metal cations $\left(\mathrm{M}^{2+}\right)$ by coulombic forces. Secondly, the abundant protons $\left(\mathrm{H}^{+}\right)$compete with the metal cations for adsorption. Thirdly, as the $\mathrm{pH}$ increases the concentrations of the metal hydroxyl complexes $\left(\mathrm{MOH}^{+}\right)$, which have higher affinity to metal oxides and hydroxides surfaces, become significant and this causes an abrupt increase in metal adsorption [34]. Fourthly, when the $\mathrm{pH}$ further increases the metal initially precipitates on the TNF surface before precipitation occurs in solution $[35,36]$. The abrupt increase in the adsorption occurred at $\mathrm{pH} 3-4$ for $\mathrm{Pb}, 4-6$ for $\mathrm{Cu}$ and $\mathrm{Cd}$ and 5-7 for $\mathrm{Zn}$ and Ni. This abrupt elevation in the adsorption of metals is due to the large increase in concentration of metal hydroxide complex species in solution, or degree of surface precipitation within a narrow $\mathrm{pH}$ increases as observed for heavy metal adsorption on many other adsorbents $[34,37,38]$.

The degree of metal adsorption at $\mathrm{pH} 6.5$ was in the order $\mathrm{Pb}>\mathrm{Cu}>\mathrm{Cd}>\mathrm{Zn}>\mathrm{Ni}$, which follows the order of the ease of metal precipitation (pKs)/or metal hydroxide complex formation (pK1) except Cd (Table 1). At $\mathrm{pH}<6.5$ the order changed to $\mathrm{Pb}>\mathrm{Cd}>\mathrm{Cu}>\mathrm{Zn}>\mathrm{Ni}$. This is probably because at low $\mathrm{pH}$, instead of metals forming significant amounts of hydroxyl complexes they exist as hydrated divalent ions where the tendency for adsorption depends on the hydrated ionic radius and hydration energy. Ions with smaller hydrated ionic radius are able to move closer to the adsorbent surface as well as easily enter the channels in the adsorbent for preferential adsorption. Ions with low hydration energies can easily become dehydrated and shrink in size for greater adsorption [37]. On this basis, $\mathrm{Pb}$ with the lowest hydrated radius and hydration energy has produced the highest degree of adsorption, followed by $\mathrm{Cd}, \mathrm{Cu}, \mathrm{Zn}$, and $\mathrm{Ni}$ in that order. Similar orders of adsorption were observed by others for $\mathrm{Pb}, \mathrm{Cu}, \mathrm{Cd}$, and $\mathrm{Zn}$ on a titanosilicate at $\mathrm{pH} 5$ [37] and $\mathrm{Pb}, \mathrm{Cd}$, and $\mathrm{Zn}$ on a zeolite and granular activated carbon ([39], $\mathrm{pH}$ not reported), and $\mathrm{Pb}, \mathrm{Cd}, \mathrm{Cu}$, and $\mathrm{Cr}$ on a titanate nanotube at $\mathrm{pH} 5$ [40].

\section{FIG. 4}

\section{TABLE 1}




\subsubsection{Langmuir adsorption model}

The batch adsorption data were analysed using the Langmuir model (equation 3):

$\mathrm{Q}_{\mathrm{e}}=\frac{\mathrm{q}_{\max } \mathrm{K}_{\mathrm{L}} \mathrm{C}_{\mathrm{e}}}{1+\mathrm{K}_{\mathrm{L}} \mathrm{C}_{\mathrm{e}}}$

where, $\mathrm{q}_{\max }=$ maximum amount of the heavy metal adsorbed per unit weight of TNF (mg/g) and $\mathrm{K}_{\mathrm{L}}$ $=$ Langmuir adsorption constant $(\mathrm{L} / \mathrm{mg})$.

This model can be linearized as follows:

$\mathrm{C}_{\mathrm{e}} / \mathrm{Q}_{\mathrm{e}}=1 / \mathrm{q}_{\max } \mathrm{K}_{L}+\mathrm{C}_{\mathrm{e}} / \mathrm{q}_{\max }$

Plots of $\mathrm{C}_{\mathrm{e}} / \mathrm{Q}_{\mathrm{e}} \mathrm{vs} \mathrm{C}_{\mathrm{e}}$ indicated significant linear relationships for all metals at all pHs (supplementary figure (SF1); Table $2, \mathrm{R}^{2}=0.955-0.998$ ), demonstrating that the adsorption data fitted satisfactorily to the Langmuir adsorption model. This suggests that the adsorption sites on TNF were homogeneous with monolayer adsorption coverage.

\subsubsection{Single metal adsorption}

The Langmuir adsorption maxima calculated from the slope of the linear plots of $\mathrm{C}_{\mathrm{e}} / \mathrm{Q}_{\mathrm{e}} \mathrm{vs} \mathrm{C}_{\mathrm{e}}$ for the metals at different $\mathrm{pHs}$ followed the order $\mathrm{Pb}>\mathrm{Cd}>\mathrm{Cu}>\mathrm{Zn}>\mathrm{Ni}$ when the adsorption capacities were expressed as $\mathrm{mg} / \mathrm{g}$ and $\mathrm{Pb}>\mathrm{Cu}>\mathrm{Cd}>\mathrm{Zn}>\mathrm{Ni}$ when they are expressed as mmol/g (Table 2). The difference in the adsorption capacity between $\mathrm{Cu}$ and $\mathrm{Cd}$ changed in favour of $\mathrm{Cu}$ when: firstly, the data were expressed as mmole/g; and secondly, when the $\mathrm{pH}$ increased for the reasons presented in the previous section. When $\mathrm{pH}$ increased, all the metals revealed an increase in the maximum adsorption capacities up to $\mathrm{pH} 5$ and remained nearly the same beyond $\mathrm{pH} 5$ up to 6.5 . Lead adsorption capacity is presented only for $\mathrm{pH} 4.0$. The adsorption data for $\mathrm{Pb}$ at higher $\mathrm{pHs}$ could not be described using the Langmuir adsorption model because nearly all the $\mathrm{Pb}$ from the solutions were adsorbed or precipitated.

The Langmuir adsorption maxima (mg/g) of 60, 83, 115, and 149 at pH 6.5 for Ni, Zn, Cu, and $\mathrm{Cd}$, respectively, and 250 for $\mathrm{Pb}$ at $\mathrm{pH} 4.0$ (Table 2) are higher than the corresponding values at pH 5.0-7.0 of several carbon nanotubes adsorbents. These values are 7-48, 10-44, 24, 1-11 and 1-97, and agricultural and industrial wastes adsorbents of 3-26, 3-18, 6-109, 5-60, and 11-267 for Ni, Zn, $\mathrm{Cu}, \mathrm{Cd}$, and $\mathrm{Pb}$, respectively [46]. The Langmuir adsorption maxima of TNF are also higher than the values reported for the commercial ion exchange resins, Amberlite IR-120 (Langmuir adsorption maxima (mg/g) of 48, 85, 22, 100, and 84 for $\mathrm{Ni}, \mathrm{Zn}, \mathrm{Cu}, \mathrm{Cd}$, and $\mathrm{Pb}$, respectively, $\mathrm{pH}$ not reported) [47] and Lewatit CNP 80 (Langmuir adsorption maxima (mg/g) of 19, 20, 10, 5, and 73 for Ni, Zn, $\mathrm{Cu}, \mathrm{Cd}$, and $\mathrm{Pb}$, respectively, $\mathrm{pH} 8.0$ ) [48]. The adsorption capacities of TNF improve on those 
reported for a similar titanate material (microporous titanosilicate) (11, 27, 41, and $170 \mathrm{mg} / \mathrm{g}$ for Zn, $\mathrm{Cu}, \mathrm{Cd}$, and $\mathrm{Pb}$, respectively, $\mathrm{pH}$ 5.0) [37].

\section{TABLE 2}

\subsubsection{Mixed metals adsorption}

The data for the adsorption of metals from solutions containing mixed metals showed that at equilibrium concentrations greater than 2-4 $\mathrm{mg} / \mathrm{L}$, the adsorption of all metals except $\mathrm{Pb}$ decreased at both low and high pHs (Fig. 5). The reason for this decrease is that at high concentrations of the metals, these metals competed for adsorption on the limited number of unoccupied adsorption sites on the TNF surface. The weakly adsorbed metals, $\mathrm{Ni}$ and $\mathrm{Zn}$, showed a greater reduction in adsorption than the other metals.

\section{TABLE 3}

FIG. 5

Since greater competition for adsorption of metals occurred at high solution metal concentrations, the adsorption data were divided into two groups: one at solution concentrations of 0 $3 \mathrm{mg} / \mathrm{L}$; and the other at $>3 \mathrm{mg} / \mathrm{L}$. When the data were fitted to the Langmuir adsorption model, results showed that both groups of data satisfactorily fitted to the model (Table 3; $\mathrm{R}^{2}=0.935-0.999$ low concentrations; $\mathrm{R}^{2}=0.698-0.981$ high concentrations, Supplementary figures SF2 and SF3). However, the fits were better at low solution concentrations than at high ones and when the entire concentration ranges were considered for all metals except $\mathrm{Pb}\left(\mathrm{R}^{2}=0.772-0.992\right)$. For $\mathrm{Pb}$, the whole concentration range was less than $3 \mathrm{mg} / \mathrm{L}$, probably due to significant surface precipitation of $\mathrm{Pb}(\mathrm{OH})_{2}$ above this concentration range, and therefore the above comparison was not possible. To determine whether other adsorption models could explain the data at both low and high metals concentrations better than the Langmuir model, the adsorption data was modelled using Freundlich and Dubinin-Radushkevick models (REF). However, the data fit to these models were less satisfactory than the Langmuir fits (Supplementary tables ST 1 and 2). Langmuir adsorption maxima for all metals except $\mathrm{Pb}$ were higher at lower solution metal concentrations than for the entire concentration range. As explained earlier this is due to greater competition between metals for adsorption at higher concentrations. The adsorption maxima followed the order $\mathrm{Cu}>\mathrm{Cd}>\mathrm{Zn}>\mathrm{Ni}$ at 
low metal concentration ranges and at the entire concentration ranges whether they were expressed as $\mathrm{mg} / \mathrm{g}$ or $\mathrm{mmol} / \mathrm{g}$ (Table 3).

\subsubsection{Metals desorption and TNF regeneration}

The data on adsorption/desorption of metals showed that $0.1 \mathrm{M} \mathrm{HNO}_{3}$ desorbed nearly $100 \%$ of the adsorbed $\mathrm{Zn}, \mathrm{Cd}, \mathrm{Cu}$, and $\mathrm{Ni}$ but only $12 \%$ of $\mathrm{Pb}$ (Table 4). However, desorption of all the metals using $0.1 \mathrm{M} \mathrm{NaNO}_{3}$ was poor (0.7-35\%). The adsorption capacities after the desorption process were very much reduced for many metals, especially after desorption with $0.1 \mathrm{M} \mathrm{HNO}_{3}$. In contrast to desorption using these two reagents, when the metals were desorbed using $0.1 \mathrm{M} \mathrm{HNO}_{3}$ and TNF was regenerated by adding $0.1 \mathrm{M} \mathrm{NaOH}$, the TNF almost regained its original adsorption capacity for all metals. Wang et al. [19] also reported that this method was effective in regenerating titanate nanotubes (TNT) adsorbent. They stated that during metals desorption using acid the TNT's structure and morphology changed due to losing Na from the structure. This in turn reduced the adsorption capacity but adding $\mathrm{NaOH}$ neutralized the acid and introduced $\mathrm{Na}$ so that the adsorption capacity was restored.

\section{TABLE 4}

\subsubsection{Fixed-bed column experiments}

\subsubsection{Single Metals}

In columns packed with only GAC the metals' breakthrough occurred faster and the breakthrough curves were steeper for $\mathrm{Ni}, \mathrm{Zn}$, and $\mathrm{Cd}$ whereas the breakthrough was the slowest and the curves were least steep for $\mathrm{Pb}$ (Fig. 6). The characteristic of the curve for $\mathrm{Cu}$ was in between $\mathrm{Pb}$ and the other metals. The patterns of the breakthrough curves are reflected in the order of the cumulative adsorption of the metals on GAC: $\mathrm{Pb}>\mathrm{Cu}>\mathrm{Cd}>\mathrm{Zn}>\mathrm{Ni}$ (Table 5).

\section{FIG. 6}

\section{TABLE 5}


The breakthrough curves for all the metals were less steep and the breakthroughs were slower when TNF was added to GAC in the column (Fig. 6) because of the much greater adsorption capacity of TNF compared to GAC. The adsorption capacity of TNF in the presence of GAC was calculated to be 10-20 times higher than that of GAC (Table 4). However, the order of the cumulative adsorption of metals on GAC + TNF remained the same as in the GAC-only column $(\mathrm{Pb}>\mathrm{Cu}>\mathrm{Cd}>\mathrm{Zn}>>\mathrm{Ni})$. The contribution of TNF to adsorption in the GAC + TNF column was assessed by subtracting the cumulative adsorption by GAC from that of GAC + TNF. The results showed that TNF strongly influenced the removal of $\mathrm{Cd}$. This is consistent with the results of the batch adsorption study where the Langmuir adsorption capacity of TNF followed the order $\mathrm{Pb}>\mathrm{Cd}>\mathrm{Cu}>\mathrm{Zn}>\mathrm{Ni}$ at low pHs (Table 2). Adsorption capacity of TNF for Pb obtained by the above calculation is low because of the high adsorption capacity of Pb on GAC (Table 5).

\subsubsection{Simultaneous removal of metals}

The patterns of metals breakthrough from solutions containing mixed metals (Fig. 7) were similar to those of solutions containing single metals (Fig. 7). The steepness of the breakthrough curves followed the order $\mathrm{Ni}>\mathrm{Zn}>\mathrm{Cd}>\mathrm{Cu}>\mathrm{Pb}$ in both the GAC and GAC + TNF columns as observed in the single metals experiment. The cumulative amounts of each metal adsorbed up to $16 \mathrm{~h}$ (266 bed volumes) (Table 5) were smaller than the respective metal adsorption in the single metals experiment (Table 5) due to the lower influent concentration of the metals in the mixed metals system. The order of the cumulative amounts adsorbed was $\mathrm{Pb}>\mathrm{Cu}>\mathrm{Zn}>\mathrm{Cd}>\mathrm{Ni}$ in the GAC column but it was $\mathrm{Pb}>\mathrm{Cu}>\mathrm{Cd}>\mathrm{Zn}>\mathrm{Ni}$ in GAC + TNF column. This indicates that GAC has less adsorption preference for $\mathrm{Cd}$ than $\mathrm{Zn}$ in a competitive adsorption system whereas the opposite occurred on TNF. The cumulative amounts of metals adsorbed in the GAC + TNF column were larger than those in the GAC column for all metals, thus indicating the higher adsorptive capacity of TNF. In the case of Cd the amount adsorbed was nearly 80 times larger in the GAC + TNF column.

\section{FIG. 7}

\section{Conclusions}

Batch experiments on heavy metals adsorption on TNF (zero point of charge 3.2) from solutions containing single or mixed metals showed that elevated $\mathrm{pH}$ increased the adsorption of $\mathrm{Pb}$, 
Cd, $\mathrm{Cu}, \mathrm{Zn}$ and Ni. Adsorption data at $\mathrm{pH}$ 4.0, 5.0, 5.5 and 6.5 for the single metal system fitted satisfactorily to the Langmuir isotherm model for $\mathrm{Cd}, \mathrm{Cu}, \mathrm{Zn}$ and $\mathrm{Ni}$. The Langmuir adsorption maxima at $\mathrm{pH}$ 6.5, which is the $\mathrm{pH}$ of most natural and waste waters, for these metals were 149, 115, 83 and $60 \mathrm{mg} / \mathrm{g}$, respectively. For $\mathrm{Pb}$, because TNF removed all solution $\mathrm{Pb}$ above $\mathrm{pH}$ 4.0, only the data for $\mathrm{pH} 4.0$ fitted to the Langmuir isotherm model which gave an adsorption maximum of 250 $\mathrm{mg} / \mathrm{g}$. For the mixed metal systems, the adsorption of all metals except $\mathrm{Pb}$ decreased at high solution concentration, especially for weakly adsorbed $\mathrm{Ni}$ and $\mathrm{Zn}$, due to the competition between metals for adsorption. Most waters contaminated from diffuse sources of metals have metal concentrations less than $3 \mathrm{mg} / \mathrm{L}$ and therefore their competition for adsorption on TNF is unlikely. The Langmuir adsorption capacities for $\mathrm{Cd}, \mathrm{Cu}, \mathrm{Zn}, \mathrm{Ni}$, and $\mathrm{Pb}$ in mixed metals system at $\mathrm{pH} 6.5$ were lower than the respective values in the single metal system. For the repeated use of TNF the adsorbed metals need to be desorbed and TNF regenerated. Desorption using $0.1 \mathrm{M} \mathrm{HNO}_{3}$ followed by regeneration of the TNF by the addition of $0.1 \mathrm{M} \mathrm{NaOH}$ appeared to be an efficient method.

Column experiments on TNF (4\%) mixed with GAC (96\%) in both single and mixed metal systems showed that the metals removed by adsorption varied widely and up to 80 times greater than in the column with only GAC. Metal breakthrough times decreased in the same order as the adsorption capacities in batch studies. The study showed that TNF can potentially remove a large percentage of heavy metals from polluted water. Because TNF is finer in size, it can be mixed with GAC to provide better hydraulic properties, and at the same time it can effectively remove heavy metals.

\section{Acknowledgement}

This study was funded by the Cooperative Research Centre for Contamination Assessment and Remediation of the Environment (CRC CARE) (project number 02-050-07).

\section{References}

[1] J.P. Chen, Decontamination of Heavy Metals: Processes, Mechanisms, and Applications, CRC Press, 2012.

[2] M. Nyman, D.T. Hobbs, A family of peroxo-titanate materials tailored for optimal strontium and actinide sorption, Chem. Mater. 18 (2006) 6425-6435.

[3] S. Wang, H. Sun, H.M. Ang, M.O. Tadé, Adsorptive remediation of environmental pollutants using novel graphene-based nanomaterials, Chem. Eng. J. 226 (2013) 336-347.

[4] M. Hua, S. Zhang, B. Pan, W. Zhang, L. Lv, Q. Zhang, Heavy metal removal from water/wastewater by nanosized metal oxides: A review, J. Hazard. Mater. 211-212 (2012) 317331. 
[5] B. Pan, B. Pan, W. Zhang, L. Lv, Q. Zhang, S. Zheng, Development of polymeric and polymerbased hybrid adsorbents for pollutants removal from waters, Chem. Eng. J. 151 (2009) 19-29.

[6] A. Henglein, Small-particle research: physicochemical properties of extremely small colloidal metal and semiconductor particles, Chem. Rev. 89 (1989) 1861-1873.

[7] M.A. El-Sayed, Some interesting properties of metals confined in time and nanometer space of different shapes, Acc. Chem. Res. 34 (2001) 257-264.

[8] L. Cumbal, A.K. SenGupta, Arsenic removal using polymer-supported hydrated iron(III) oxide nanoparticles: role of Donnan membrane effect, Environ. Sci. Technol. 39 (2005) 6508-6515.

[9] Y. Kikuchi, Q. Qian, M. Machida, H. Tatsumoto, Effect of ZnO loading to activated carbon on $\mathrm{Pb}$ (II) adsorption from aqueous solution, Carbon 44 (2006) 195-202.

[10] R.L. Vaughan Jr, B.E. Reed, Modeling As(V) removal by a iron oxide impregnated activated carbon using the surface complexation approach, Water Res. 39 (2005) 1005-1014.

[11] M. Jang, W. Chen, F.S. Cannon, Preloading hydrous ferric oxide into granular activated carbon for arsenic removal, Environ. Sci. Technol. 42 (2008) 3369-3374.

[12] J.M. Zhuang, E. Hobenshield, T. Walsh, Arsenate sorption by hydrous ferric oxide incorporated onto granular activated carbon with phenol formaldehyde resins coating, Environ. Technol. 29 (2008) 401-411.

[13] S.S. Liu, C.K. Lee, H.C. Chen, C.C. Wang, L.C. Juang, Application of titanate nanotubes for $\mathrm{Cu}(\mathrm{II})$ ions adsorptive removal from aqueous solution, Chem. Eng. J. 147 (2009) 188-193.

[14] I. El Saliby, L. Erdei, H.K. Shon, J.B. Kim, J.H. Kim, Preparation and characterisation of mesoporous photoactive Na-titanate microspheres, Catal. Today 164 (2011) 370-376.

[15] Y. Hang, H. Yin, A. Wang, L. Shen, Y. Feng, R. Liu, Preparation of titanate whiskers starting from metatitanic acid and their adsorption performances for $\mathrm{Cu}(\mathrm{II}), \mathrm{Pb}(\mathrm{II})$, and $\mathrm{Cr}(\mathrm{III})$ ions, Water Air Soil Pollut. 225 (2014) 1-14.

[16] G. Sheng, B. Hu, Role of solution chemistry on the trapping of radionuclide Th(IV) using titanate nanotubes as an efficient adsorbent, J. Radioanal. Nucl. Chem. 298 (2013) 455-464.

[17] K.E. Engates, H.J. Shipley, Adsorption of $\mathrm{Pb}, \mathrm{Cd}, \mathrm{Cu}, \mathrm{Zn}$, and $\mathrm{Ni}$ to titanium dioxide nanoparticles: effect of particle size, solid concentration, and exhaustion, Environ. Sci. Pollut. R. 18 (2011) 386-395.

[18] J. Huang, Y. Cao, Z. Liu, Z. Deng, F. Tang, W. Wang, Efficient removal of heavy metal ions from water system by titanate nanoflowers, Chem. Eng. J. 180 (2012) 75-80.

[19] T. Wang, W. Liu, N. Xu, J. Ni, Adsorption and desorption of Cd(II) onto titanate nanotubes and efficient regeneration of tubular structures, J. Hazard. Mater., 250-251 (2013) 379-386.

[20] J.P. Chen, J.T. Yoon, S. Yiacoumi, Effects of chemical and physical properties of influent on copper sorption onto activated carbon fixed-bed columns, Carbon, 41 (2003) 1635-1644.

[21] R. Aryal, B.K. Lee, Characteristics of suspended solids and micropollutants in first-flush highway runoff, Water Air Soil Pollut. 9 (2009) 339-346.

[22] F. Nie, T. Li, H. Yao, M. Feng, G. Zhang, Characterization of suspended solids and particlebound heavy metals in a first flush of highway runoff, J. Zhejiang. Univ-Sc. A 9 (2008) 15671575.

[23] J. Huang, Y. Cao, Q. Huang, H. He, Y. Liu, W. Guo, M. Hong, High-temperature formation of titanate nanotubes and the transformation mechanism of nanotubes into nanowires, Cryst. Growth. Des. 9 (2009) 3632-3637.

[24] M. Yada, Y. Goto, M. Uota, T. Torikai, T. Watari, Layered sodium titanate nanofiber and microsphere synthesized from peroxotitanic acid solution, J. Eur. Ceram. Soc. 26 (2006) 673678.

[25] J. Seo, Y. Jun, S.J. Ko, J. Cheon, In situ one-pot synthesis of 1-dimensional transition metal oxide nanocrystals, J. Phys. Chem. B 109 (2005) 5389-5391.

[26] T. Wang, W. Liu, L. Xiong, N. Xu, J. Ni, Influence of pH, ionic strength and humic acid on competitive adsorption of $\mathrm{Pb}(\mathrm{II}), \mathrm{Cd}(\mathrm{II})$ and $\mathrm{Cr}(\mathrm{III})$ onto titanate nanotubes, Chem. Eng. J. 215216 (2013) 366-374.

[27] R.A. Zárate, S. Fuentes, A.L. Cabrera, V.M. Fuenzalida, Structural characterization of single crystals of sodium titanate nanowires prepared by hydrothermal process, J. Cryst. Growth 310 (2008) 3630-3637. 
[28] J. Huang, Z. Huang, W. Guo, M. Wang, Y. Cao, M. Hong, Facile synthesis of titanate nanoflowers by a hydrothermal route, Cryst. Growth. Des. 8 (2008) 2444-2446.

[29] J. Yang, Z. Jin, X. Wang, W. Li, J. Zhang, S. Zhang, X. Guo, Z. Zhang, Study on composition, structure and formation process of nanotube $\mathrm{Na}_{2} \mathrm{Ti}_{2} \mathrm{O}_{4}(\mathrm{OH})_{2}$, Dalton Trans. (2003) 3898-3901.

[30] Y.C. Chen, S.L. Lo, J. Kuo, Pb(II) adsorption capacity and behavior of titanate nanotubes made by microwave hydrothermal method, Colloid Surf. A 361 (2010) 126-131.

[31] T. Kubo, A. Nakahira, Local structure of $\mathrm{TiO}_{2}$-derived nanotubes prepared by the hydrothermal process, J. Phys. Chem. C 112 (2008) 1658-1662.

[32] J. Huang, Y. Cao, M. Wang, C. Huang, Z. Deng, H. Tong, Z. Liu, Tailoring of low-dimensional titanate nanostructures, J. Phys. Chem. C 114 (2010) 14748-14754.

[33] S.D. Faust, O.M. Aly, Adsorption processes for water treatment, Butterworth, Boston, 1987.

[34] P. Huang, D.W. Fuerstenau, The effect of the adsorption of lead and cadmium ions on the interfacial behavior of quartz and talc, Colloid Surf. A 177 (2001) 147-156.

[35] P. Loganathan, S. Vigneswaran, J. Kandasamy, N.S. Bolan, Removal and recovery of phosphate from water using sorption, Crit. Rev. Environ. Sci. Technol. 44 (2014) 847-907.

[36] M. Erdemoğlu, M. Sarıkaya, Effects of heavy metals and oxalate on the zeta potential of magnetite, J. Colloid Interface Sci. 300 (2006) 795-804.

[37] L. Lv, G. Tsoi, X.S. Zhao, Uptake equilibria and mechanisms of heavy metal ions on microporous titanosilicate ETS-10, Ind. Eng. Chem. Res. 43 (2004) 7900-7906.

[38] P. Loganathan, R.G. Burau, D.W. Fuerstenau, Influence of $\mathrm{pH}$ on the sorption of $\mathrm{Co}^{2+}, \mathrm{Zn}^{2+}$ and $\mathrm{Ca}^{2+}$ by a hydrous manganese oxide, Soil Sci. Soc. Amer. J. 41 (1977) 57-62.

[39] M. Minceva, L. Markovska, V. Meshko, Removal of $\mathrm{Zn}^{2+}, \mathrm{Cd}^{2+}$ and $\mathrm{Pb}^{2+}$ from binary aqueous solution by natural zeolite and granulated activated carbon, Maced. J. Chem. Chem. Eng. 26 (2007) 125-134.

[40] W. Liu, T. Wang, A.G.L. Borthwick, Y. Wang, X. Yin, X. Li, J. Ni, Adsorption of $\mathrm{Pb}^{2+}, \mathrm{Cd}^{2+}$, $\mathrm{Cu}^{2+}$ and $\mathrm{Cr}^{3+}$ onto titanate nanotubes: Competition and effect of inorganic ions, Sci. Total Environ. 456-457 (2013) 171-180.

[41] Y. Marcus, Thermodynamics of solvation of ions. Part 5.-Gibbs free energy of hydration at 298.15 K, J. Chem. Soc. Faraday Trans. 87 (1991) 2995-2999.

[42] J.D. Walker, M.C. Newman, M. Enache, Fundamental QSARs for Metal Ions, CRC Press, 2012.

[43] S.R. Rao, Resource Recovery and Recycling from Metallurgical Wastes, Elsevier, 2011.

[44] D.W. Barnum, Hydrolysis of Cations. Formation constants and standard free energies of formation of hydroxy complexes, Inorg. Chem. 22 (1983) 2297-2305.

[45] C.F. Baes, R.E. Mesmer, Hydrolysis of cations, Wiley, New York, 1976.

[46] G.P. Rao, C. Lu, F. Su, Sorption of divalent metal ions from aqueous solution by carbon nanotubes: A review, Sep. Purif. Technol., 58 (2007) 224-231.

[47] A. Demirbas, E. Pehlivan, F. Gode, T. Altun, G. Arslan, Adsorption of $\mathrm{Cu}(\mathrm{II}), \mathrm{Zn}(\mathrm{II}), \mathrm{Ni}(\mathrm{II})$, $\mathrm{Pb}(\mathrm{II})$, and $\mathrm{Cd}(\mathrm{II})$ from aqueous solution on Amberlite IR-120 synthetic resin, J. Colloid Interface Sci., 282 (2005) 20-25.

[48] E. Pehlivan, T. Altun, Ion-exchange of $\mathrm{Pb}^{2+}, \mathrm{Cu}^{2+}, \mathrm{Zn}^{2+}, \mathrm{Cd}^{2+}$, and $\mathrm{Ni}^{2+}$ ions from aqueous solution by Lewatit CNP 80, J. Hazard. Mater., 140 (2007) 299-307. 


\section{Table 1}

Some characteristics of heavy metal ions.

\begin{tabular}{ccccc}
\hline Metal & $\begin{array}{c}\text { Hydrated radius } \\
(\mathrm{nm})\end{array}$ & $\begin{array}{c}\text { Hydrated energy } \\
(\mathrm{kJ} / \mathrm{mol})\end{array}$ & $\begin{array}{c}\text { Solubility of } \\
\text { hydroxides }\left(\mathrm{pK}_{\mathrm{S}}\right)\end{array}$ & $\begin{array}{c}\text { First hydrolysis } \\
\text { constants }\left(\mathrm{pK}_{1}\right)\end{array}$ \\
\hline $\mathrm{[41]}$ & -2005 & {$[42,43]$} & 9.86 \\
\hline $\mathrm{Ni}$ & 0.302 & -1880 & 15.2 & 8.96 \\
$\mathrm{Zn}$ & 0.295 & -1920 & 16.5 & 7.96 \\
$\mathrm{Cu}$ & 0.297 & -1575 & 19.3 & 10.08 \\
$\mathrm{Cd}$ & 0.275 & -1345 & 14.4 & 7.71 \\
$\mathrm{~Pb}$ & 0.261 & & 19.9 & \\
\hline
\end{tabular}


Table 2

Langmuir parameters for individual heavy metals adsorption on TNF (ionic strength $10^{-3} \mathrm{M} \mathrm{NaNO}_{3}$ ) and coefficients of determination for the Langmuir plots $\left(\mathrm{R}^{2}\right)$.

\begin{tabular}{|c|c|c|c|c|c|c|c|c|c|c|c|c|c|c|c|c|}
\hline \multirow[b]{2}{*}{ Metals } & \multicolumn{4}{|c|}{$\mathrm{pH} 4.0$} & \multicolumn{4}{|c|}{ pH 5.0} & \multicolumn{4}{|c|}{ pH 5.5} & \multicolumn{4}{|c|}{ pH 6.5} \\
\hline & $\begin{array}{c}\mathrm{q}_{\max } \\
(\mathrm{mg} / \mathrm{g})\end{array}$ & $\begin{array}{c}\mathrm{q}_{\max } \\
(\mathrm{mmol} / \mathrm{g})\end{array}$ & $\begin{array}{c}\mathrm{K}_{\mathrm{L}} \\
(\mathrm{L} / \mathrm{mg})\end{array}$ & $\mathrm{R}^{2}$ & $\begin{array}{c}\mathrm{q}_{\max } \\
(\mathrm{mg} / \mathrm{g})\end{array}$ & $\begin{array}{c}\mathrm{q}_{\max } \\
(\mathrm{mmol} / \mathrm{g})\end{array}$ & $\begin{array}{c}\mathrm{K}_{\mathrm{L}} \\
(\mathrm{L} / \mathrm{mg})\end{array}$ & $\mathrm{R}^{2}$ & $\begin{array}{c}\mathrm{q}_{\max } \\
(\mathrm{mg} / \mathrm{g})\end{array}$ & $\begin{array}{c}\mathrm{q}_{\max } \\
(\mathrm{mmol} / \mathrm{g})\end{array}$ & $\begin{array}{c}\mathrm{K}_{\mathrm{L}} \\
(\mathrm{L} / \mathrm{mg})\end{array}$ & $\mathrm{R}^{2}$ & $\begin{array}{c}\mathrm{q}_{\max } \\
(\mathrm{mg} / \mathrm{g})\end{array}$ & $\begin{array}{c}\mathrm{q}_{\max } \\
(\mathrm{mmol} / \mathrm{g})\end{array}$ & $\begin{array}{c}\mathrm{K}_{\mathrm{L}} \\
(\mathrm{L} / \mathrm{mg})\end{array}$ & $\mathrm{R}^{2}$ \\
\hline $\mathrm{Ni}$ & 37 & 0.62 & 4.6 & 0.960 & 63 & 1.08 & 26.3 & 0.982 & 69 & 1.19 & 2.2 & 0.992 & 60 & 1.02 & 13.9 & 0.992 \\
\hline $\mathrm{Zn}$ & 47 & 0.72 & 13.0 & 0.981 & 70 & 1.07 & 71.5 & 0.961 & 79 & 1.21 & 9.1 & 0.985 & 83 & 1.26 & 24.2 & 0.972 \\
\hline $\mathrm{Cu}$ & 54 & 0.85 & 18.5 & 0.996 & 75 & 1.17 & 10.3 & 0.983 & 99 & 1.56 & 6.7 & 0.955 & 115 & 1.81 & 17.4 & 0.993 \\
\hline $\mathrm{Cd}$ & 93 & 0.83 & 5.9 & 0.978 & 159 & 1.41 & 10.5 & 0.994 & 143 & 1.27 & 11.7 & 0.988 & 149 & 1.33 & 10.5 & 0.992 \\
\hline
\end{tabular}


Table 3

Langmuir parameters for heavy metals adsorption on TNF from mixed metals solutions (ionic strength $10^{-3} \mathrm{M} \mathrm{NaNO}_{3}$ ) and coefficients of determination for the Langmuir plots $\left(\mathrm{R}^{2}\right)$ (n denotes number of data points).

\section{Data for all metal concentrations}

\begin{tabular}{|c|c|c|c|c|c|c|c|c|}
\hline \multirow[b]{2}{*}{ Metals } & \multicolumn{4}{|c|}{ pH 5.0} & \multicolumn{4}{|c|}{$\mathrm{pH} 6.5$} \\
\hline & $\begin{array}{c}\mathrm{q}_{\max } \\
(\mathrm{mg} / \mathrm{g})\end{array}$ & $\begin{array}{c}\mathrm{q}_{\max } \\
(\mathrm{mmol} / \mathrm{g})\end{array}$ & $\mathrm{R}^{2}$ & $\mathrm{n}$ & $\begin{array}{c}\mathrm{q}_{\max } \\
(\mathrm{mg} / \mathrm{g})\end{array}$ & $\begin{array}{c}\mathrm{q}_{\max } \\
(\mathrm{mmol} / \mathrm{g})\end{array}$ & $\mathrm{R}^{2}$ & $\mathrm{n}$ \\
\hline $\mathrm{Ni}$ & 6.5 & 0.11 & 0.828 & 16 & 7.5 & 0.13 & 0.899 & 9 \\
\hline $\mathrm{Zn}$ & 9.5 & 0.15 & 0.884 & 16 & 7.0 & 0.10 & 0.772 & 9 \\
\hline Cd & 22.0 & 0.20 & 0.950 & 11 & 29.0 & 0.25 & 0.984 & 9 \\
\hline $\mathrm{Cu}$ & 34.0 & 0.53 & 0.981 & 11 & 39.0 & 0.62 & 0.992 & 9 \\
\hline $\mathrm{Pb}$ & 322.5 & 1.56 & 0.938 & 15 & 333.5 & 1.61 & 0.953 & 13 \\
\hline
\end{tabular}

Data separated into low $(\mathrm{L})$ and high $(\mathrm{H})$ metal concentrations

\begin{tabular}{|c|c|c|c|c|c|c|c|c|}
\hline \multirow[b]{2}{*}{ Metals } & \multicolumn{4}{|c|}{ pH 5.0 (L) } & \multicolumn{4}{|c|}{ pH $5.0(\mathrm{H})$} \\
\hline & $\begin{array}{c}\mathrm{q}_{\max } \\
(\mathrm{mg} / \mathrm{g})\end{array}$ & $\begin{array}{c}\mathrm{q}_{\max } \\
(\mathrm{mmol} / \mathrm{g})\end{array}$ & $\mathrm{R}^{2}$ & $\mathrm{n}$ & $\begin{array}{c}\mathrm{q}_{\max } \\
(\mathrm{mg} / \mathrm{g})\end{array}$ & $\begin{array}{c}\mathrm{q}_{\max } \\
(\mathrm{mmol} / \mathrm{g})\end{array}$ & $\mathrm{R}^{2}$ & $\mathrm{n}$ \\
\hline $\mathrm{Ni}$ & 13.5 & 0.23 & 0.989 & 8 & 2.0 & 0.03 & 0.802 & 8 \\
\hline $\mathrm{Zn}$ & 16.0 & 0.25 & 0.987 & 9 & 3.5 & 0.05 & 0.812 & 7 \\
\hline Cd & 31.0 & 0.27 & 0.999 & 6 & 12.0 & 0.11 & 0.936 & 5 \\
\hline $\mathrm{Cu}$ & 40.0 & 0.63 & 0.995 & 6 & 24.0 & 0.38 & 0.960 & 5 \\
\hline $\mathrm{Pb}$ & 322.5 & 1.56 & 0.938 & 15 & - & - & - & - \\
\hline
\end{tabular}

\begin{tabular}{|c|c|c|c|c|c|c|c|c|}
\hline \multirow[b]{2}{*}{ Metals } & \multicolumn{4}{|c|}{$\mathrm{pH} 6.5(\mathrm{~L})$} & \multicolumn{4}{|c|}{ pH $6.5(\mathrm{H})$} \\
\hline & $\begin{array}{c}\mathrm{q}_{\max } \\
(\mathrm{mg} / \mathrm{g})\end{array}$ & $\begin{array}{c}\mathrm{q}_{\max } \\
(\mathrm{mmol} / \mathrm{g})\end{array}$ & $\mathrm{R}^{2}$ & $\mathrm{n}$ & $\begin{array}{c}\mathrm{q}_{\max } \\
(\mathrm{mg} / \mathrm{g})\end{array}$ & $\begin{array}{c}\mathrm{q}_{\max } \\
(\mathrm{mmol} / \mathrm{g})\end{array}$ & $\mathrm{R}^{2}$ & $\mathrm{n}$ \\
\hline $\mathrm{Ni}$ & 14.0 & 0.24 & 0.982 & 5 & 3.5 & 0.06 & 0.946 & 5 \\
\hline $\mathrm{Zn}$ & 21.5 & 0.33 & 0.988 & 5 & 3.0 & 0.05 & 0.698 & 5 \\
\hline $\mathrm{Cd}$ & 36.0 & 0.32 & 0.997 & 5 & 25.5 & 0.23 & 0.974 & 5 \\
\hline $\mathrm{Cu}$ & 39.5 & 0.62 & 0.998 & 5 & 37.0 & 0.58 & 0.981 & 5 \\
\hline $\mathrm{Pb}$ & 333.5 & 1.61 & 0.953 & 13 & - & - & - & - \\
\hline
\end{tabular}


Table 4

Adsorption/desorption of metals on TNF (mg/g)

\begin{tabular}{lccccc}
\hline & $\mathrm{Ni}$ & $\mathrm{Zn}$ & $\mathrm{Cd}$ & $\mathrm{Cu}$ & $\mathrm{Pb}$ \\
\hline Amount adsorbed in original TNF & 14.0 & 14.6 & 14.4 & 15.4 & 19.2 \\
Amount desorbed using 0.1 $\mathrm{M} \mathrm{NaNO}_{3}$ & 4.9 & 1.7 & 0.1 & 0.5 & 4.0 \\
Amount desorbed using 0.1 $\mathrm{M} \mathrm{HNO}_{3}$ & 14.2 & 14.8 & 14.4 & 15.1 & 2.4 \\
Amount adsorbed after desorption with $0.1 \mathrm{M} \mathrm{NaNO}_{3}$ & 0.0 & 1.7 & 12.1 & 13.8 & 21.3 \\
Amount adsorbed after desorption with 0.1 $\mathrm{M} \mathrm{HNO}_{3}$ & 0.6 & 1.0 & 2.4 & 3.6 & 19.4 \\
Amount adsorbed after desorption with 0.1 $\mathrm{M} \mathrm{HNO}_{3}$ & & & & & \\
and TNF regeneration with 0.2 M NaOH & 11.9 & 12.8 & 13.9 & 15.1 & 19.1 \\
\hline
\end{tabular}




\section{Table 5}

Cumulative adsorption of heavy metals by GAC and GAC + TNF from single metals and mixed metals solutions after $16 \mathrm{~h}$ (266 BV) at $\mathrm{pH} 5.0$.

\begin{tabular}{|c|c|c|c|c|c|c|c|}
\hline & Column media & Units & $\mathrm{Ni}$ & $\mathrm{Zn}$ & $\mathrm{Cu}$ & $\mathrm{Cd}$ & $\mathrm{Pb}$ \\
\hline \multirow{5}{*}{$\begin{array}{l}\text { Single } \\
\text { metals } \\
\text { Experiments }\end{array}$} & GAC, $q_{\text {total }}$ & mg & 2.5 & 5.0 & 44.0 & 9.0 & 85.0 \\
\hline & $\mathrm{GAC}+\mathrm{TNF}, \mathrm{q}_{\text {total }}$ & mg & 15.5 & 29.5 & 88.5 & 70.0 & 123.0 \\
\hline & TNF, $\mathrm{q}_{\text {total }}{ }^{\mathrm{a}}$ & $\mathrm{mg}$ & 13.0 & 24.5 & 44.5 & 61.0 & 38.0 \\
\hline & $\mathrm{GAC}^{\mathrm{b}}$ & (\%) & 2.0 & 4.0 & 32.0 & 8.0 & 69.0 \\
\hline & $\mathrm{GAC}+\mathrm{TNF}^{\mathrm{b}}$ & $(\%)$ & 12.0 & 23.5 & 64.5 & 58.0 & 100.0 \\
\hline \multirow{5}{*}{$\begin{array}{l}\text { Mixed } \\
\text { metals } \\
\text { Experiments }\end{array}$} & GAC, $q_{\text {total }}$ & $\mathrm{mg}$ & 0.25 & 1.75 & 14.25 & 0.25 & 26.25 \\
\hline & $\mathrm{GAC}+\mathrm{TNF}, \mathrm{q}_{\text {total }}$ & mg & 2.50 & 8.00 & 27.25 & 20.50 & 29.50 \\
\hline & TNF, $\mathrm{q}_{\text {total }}{ }^{\mathrm{a}}$ & mg & 2.25 & 6.25 & 13.00 & 20.25 & 3.25 \\
\hline & GAC $^{b}$ & (\%) & 1.0 & 6.5 & 46.0 & 1.5 & 86.0 \\
\hline & $\mathrm{GAC}+\mathrm{TNF}^{\mathrm{b}}$ & (\%) & 9.5 & 29.5 & 87.0 & 79.5 & 96.0 \\
\hline
\end{tabular}

adsorption on TNF = adsorption on GAC + TNF minus adsorption on GAC

bercentage of cumulative metal adsorption $=$ (cumulative metal added - cumulative metal in effluent $)$

/ cumulative metal added 


\section{Figure Captions}

Fig. 1. XRD pattern of TNF (A- anatase, R- rutile, T- sodium titanate).

Fig. 2. FTIR pattern of TNF.

Fig. 3. Zeta potential of TNF and GAC (ionic strength $10^{-3} \mathrm{M} \mathrm{NaNO}_{3}$ ).

Fig. 4. Effect of equilibrium $\mathrm{pH}$ on heavy metal adsorption from single metal solutions by TNF (ionic strength $10^{-3} \mathrm{M} \mathrm{NaNO}_{3}$. Adsorption percentage $(\%)=$ metals adsorbed (mg) / metals initially present (mg) x 100).

Fig. 5. Metals adsorption by TNF from mixed metals solution at (a) pH 5.0, (b) $\mathrm{pH} 6.5$ (ionic strength $10^{-3} \mathrm{M} \mathrm{NaNO}_{3}$ ).

Fig. 6. Breakthrough plots of (a) Ni, (b) Zn, (c) Cu, (d) Cd and (e) Pb in GAC and GAC + TNF column study for single metals.

Fig. 7. Breakthrough plots of (a) Ni, (b) Zn, (c) Cu, (d) Cd and (e) Pb in GAC and GAC + TNF column study for mixed metals. 


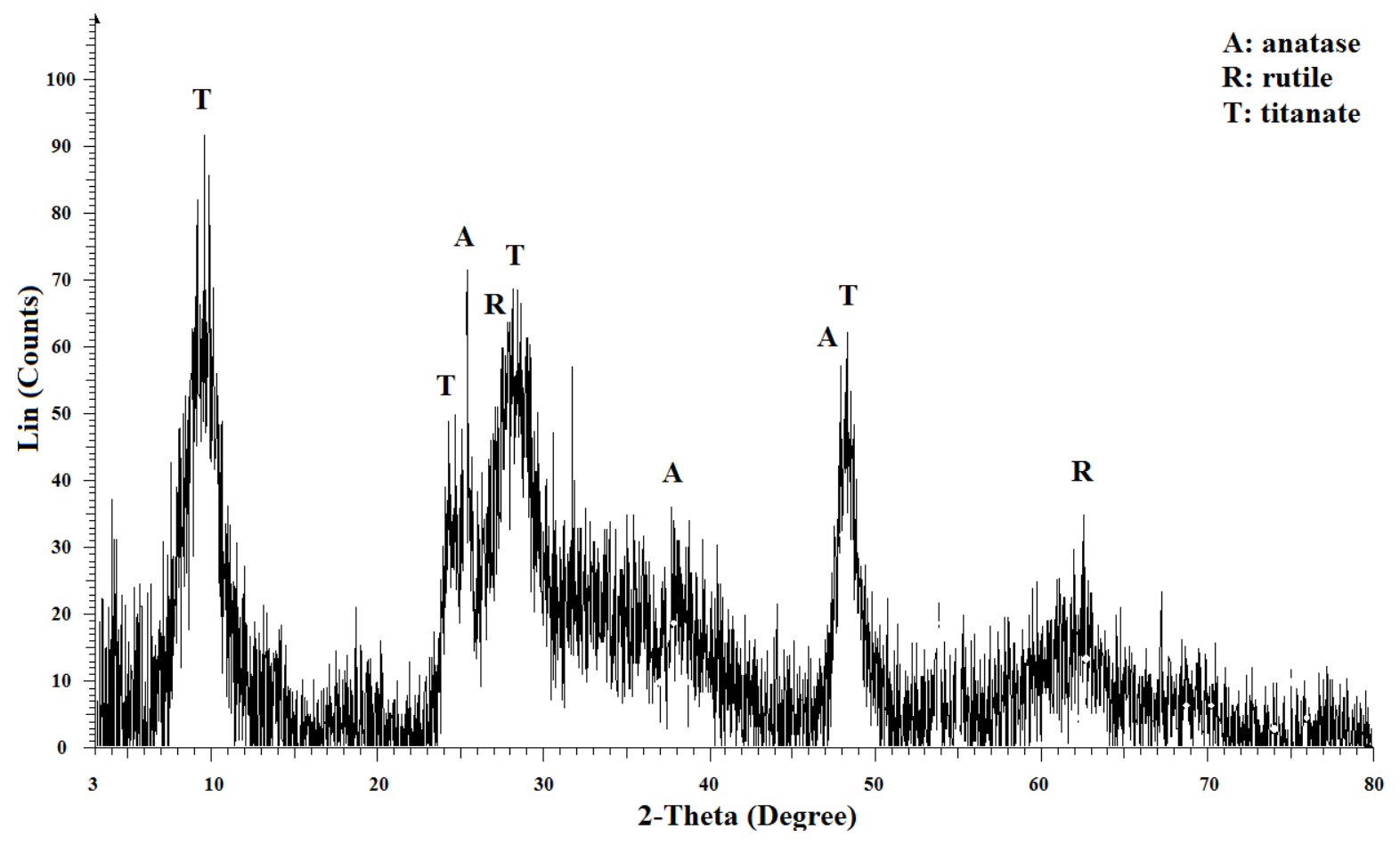

Fig. 1 


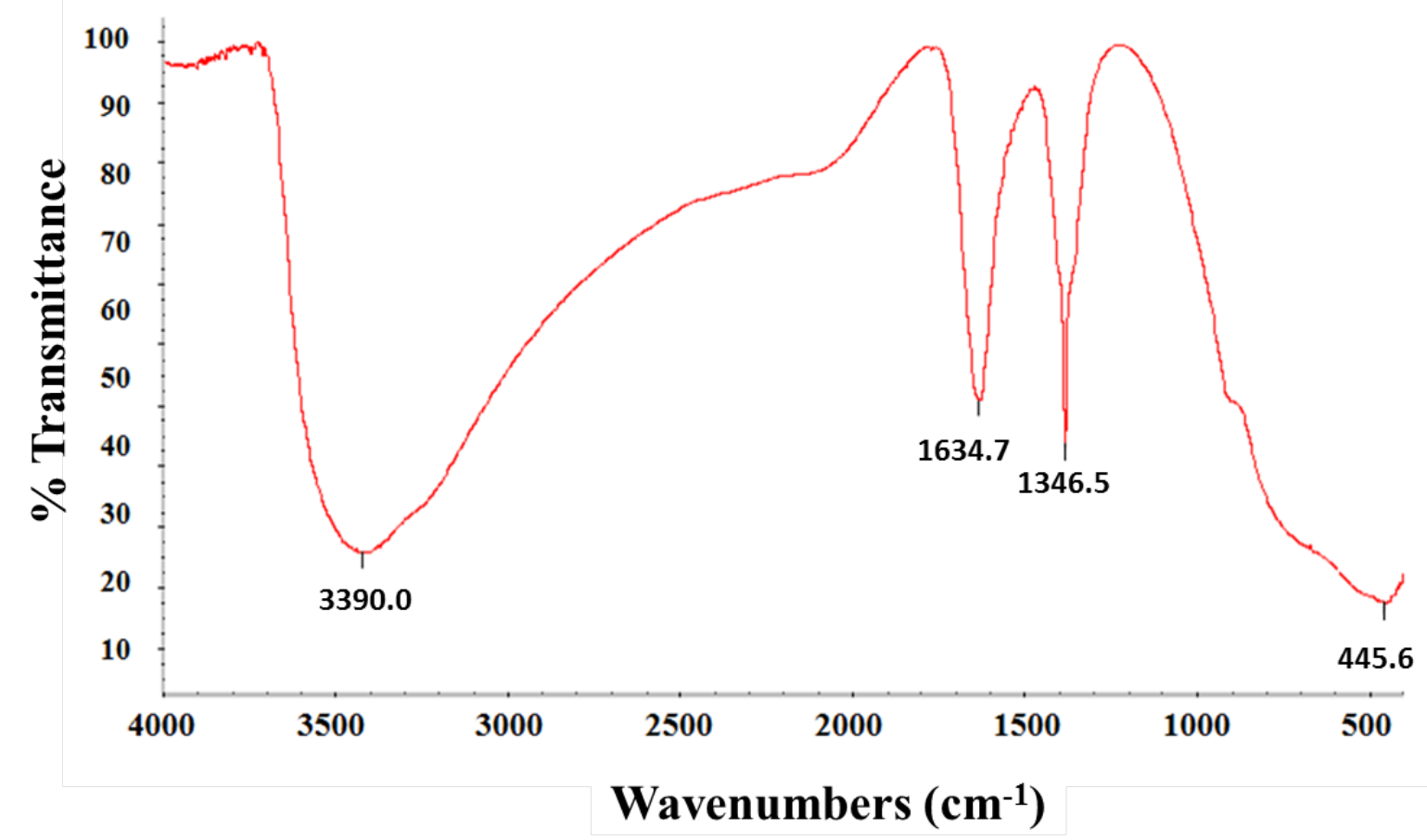

Fig. 2. 


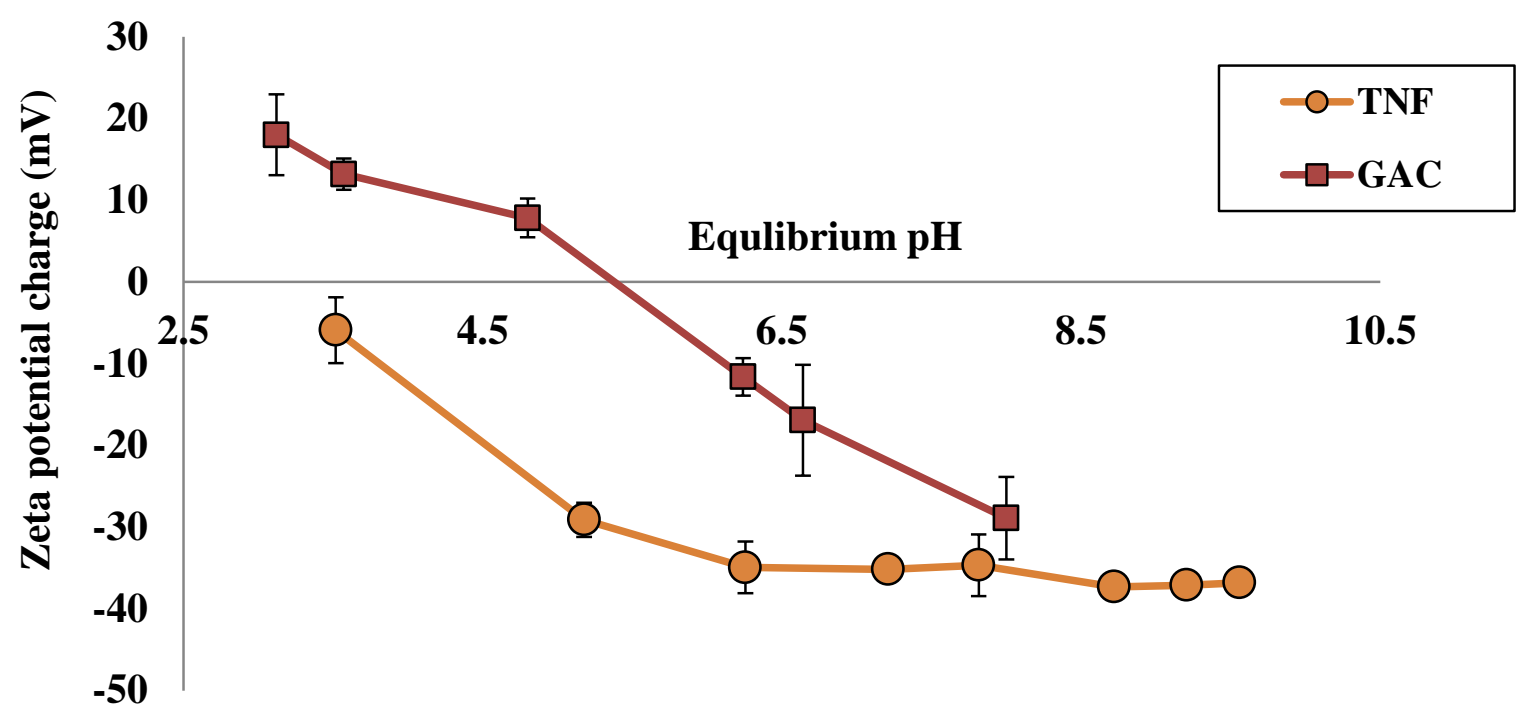

Fig. 3. 


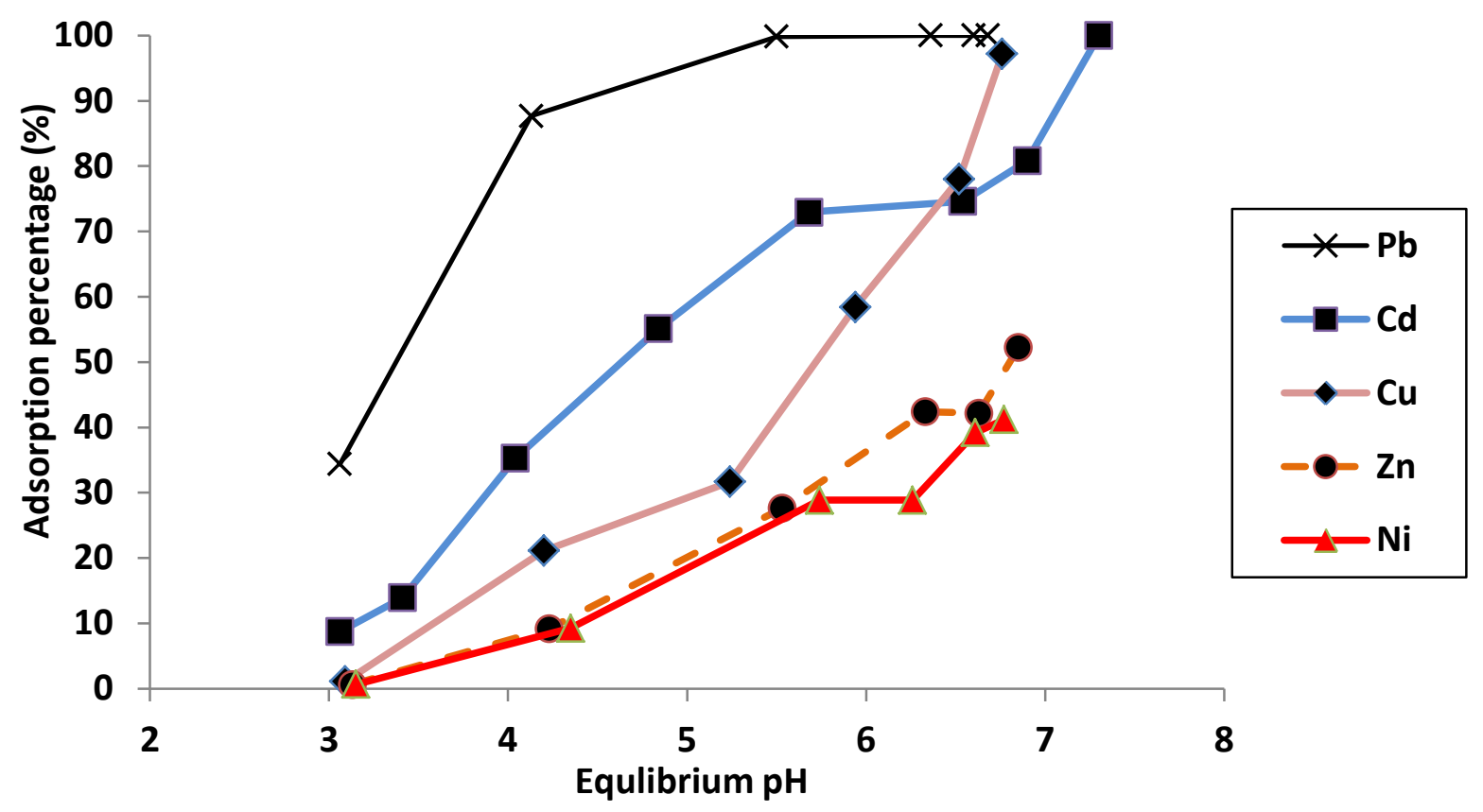

Fig. 4. 
(a)

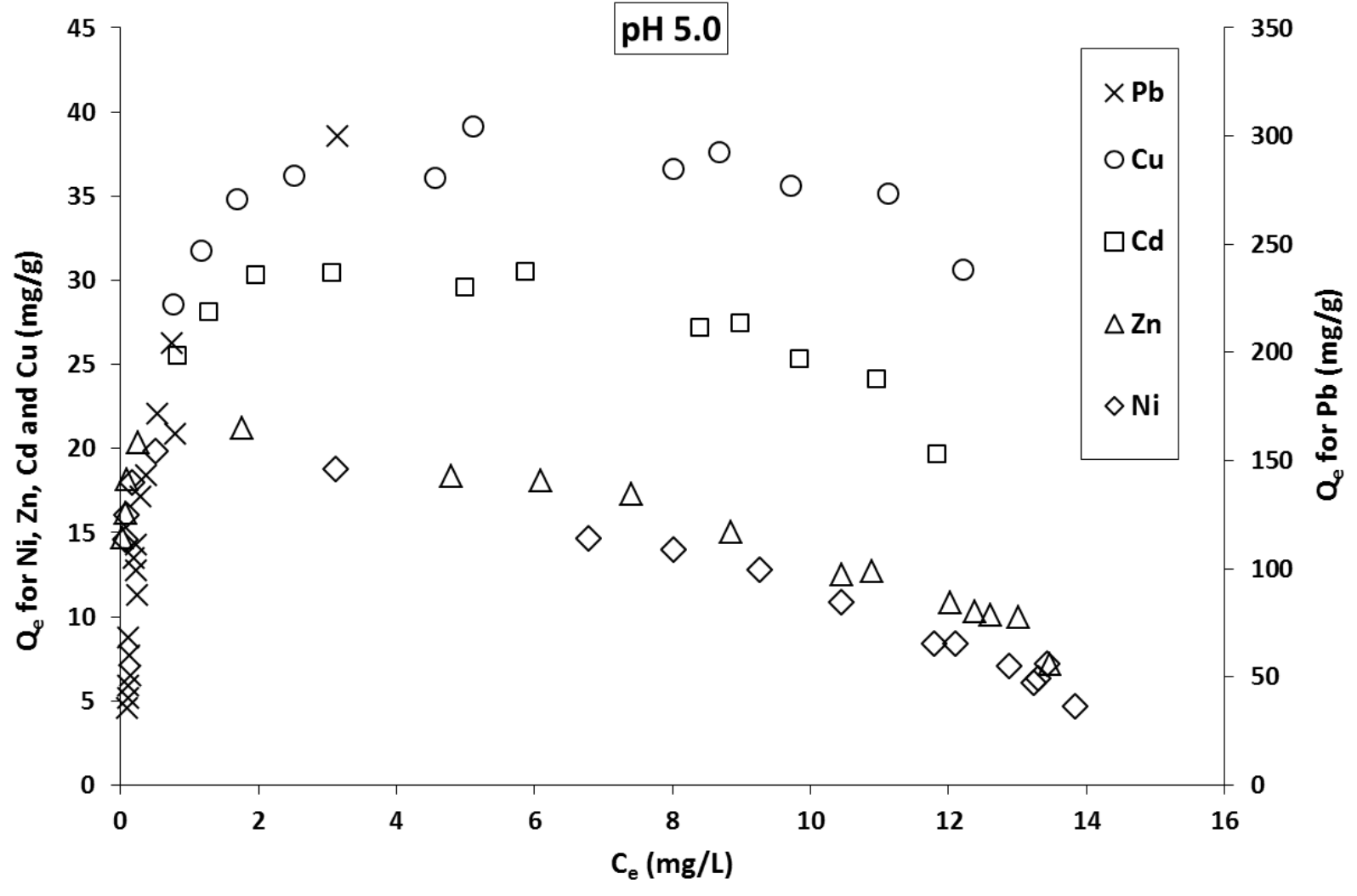

(b)

\section{pH 6.5}

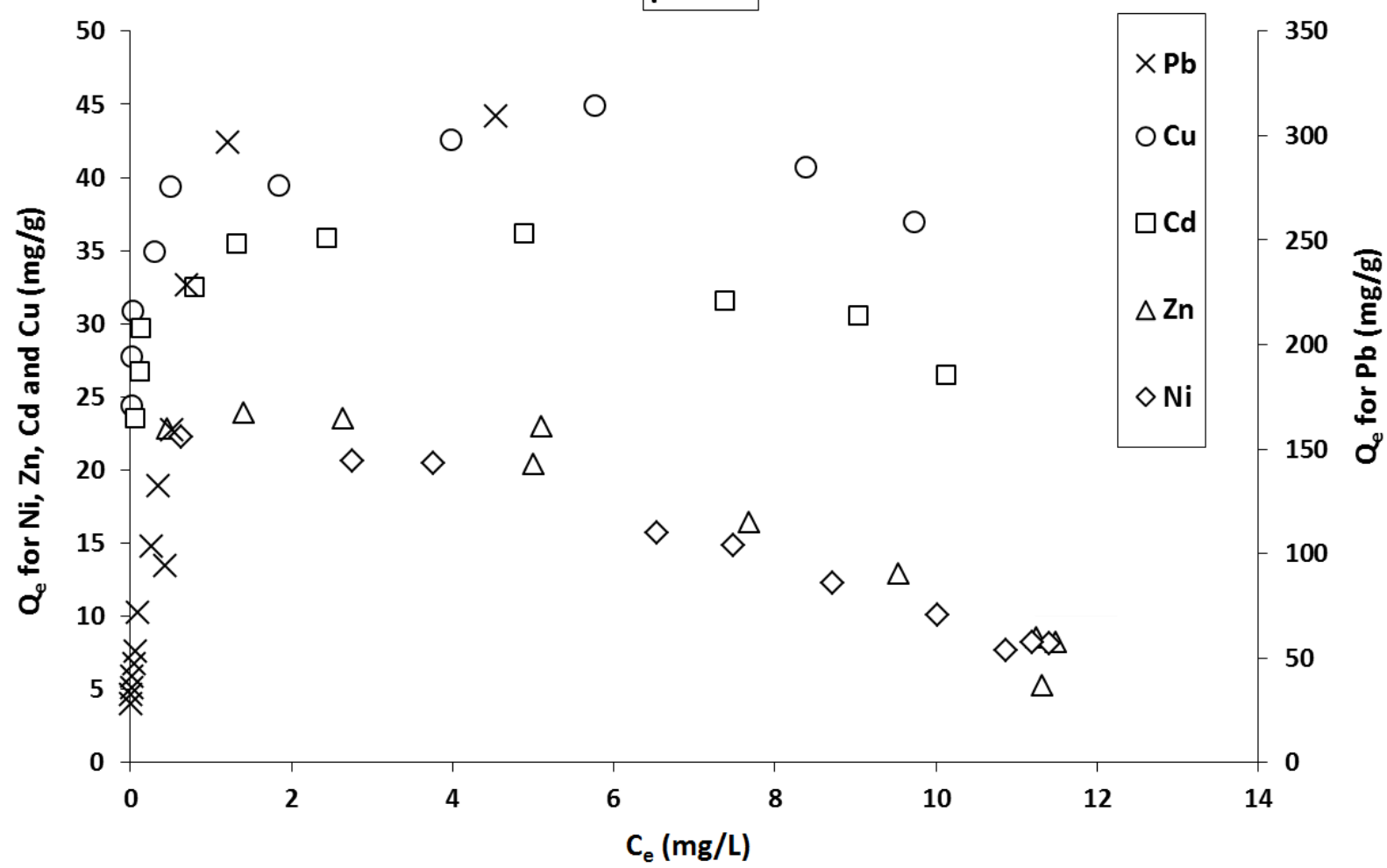

Fig. 5. 

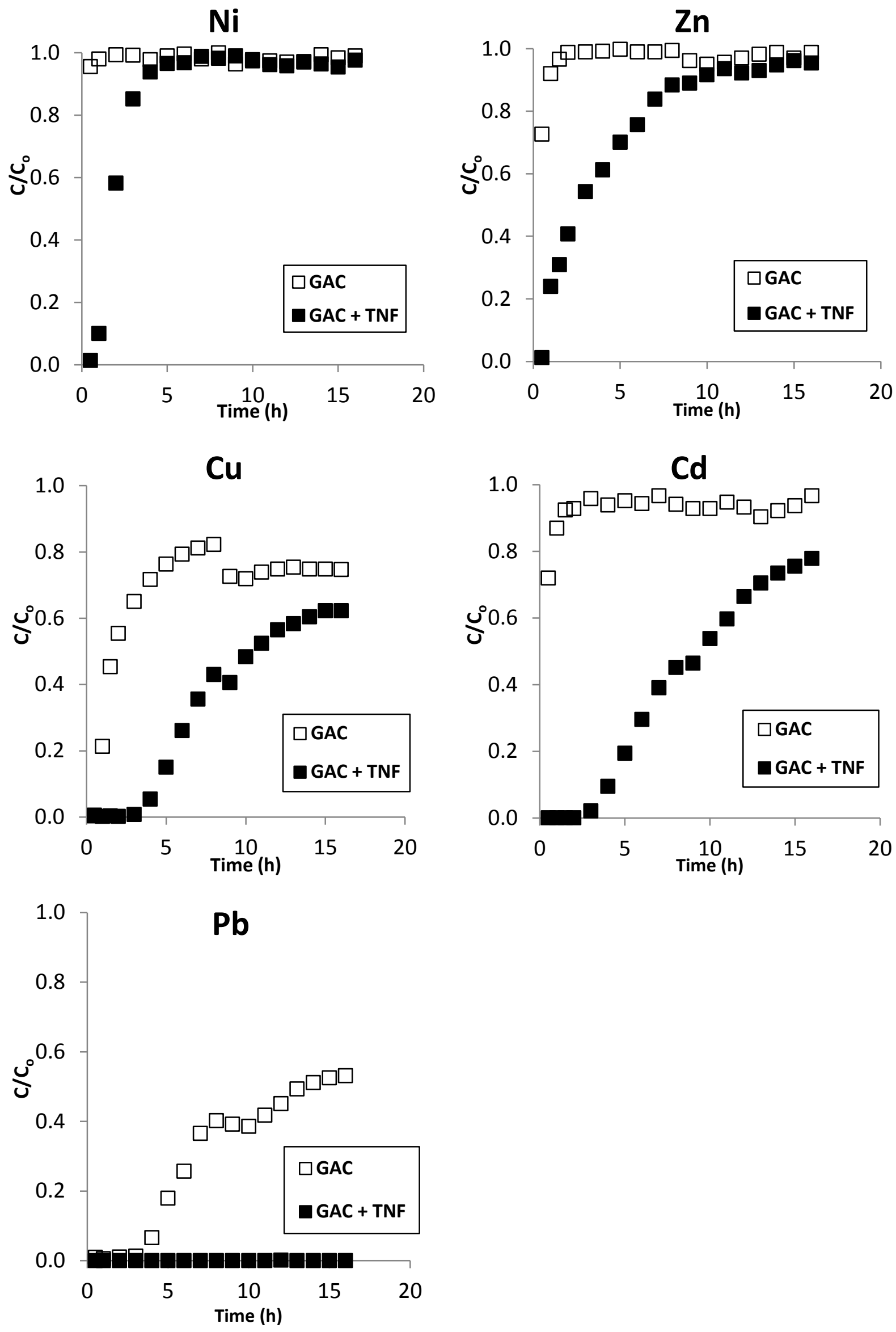

Fig. 6. 

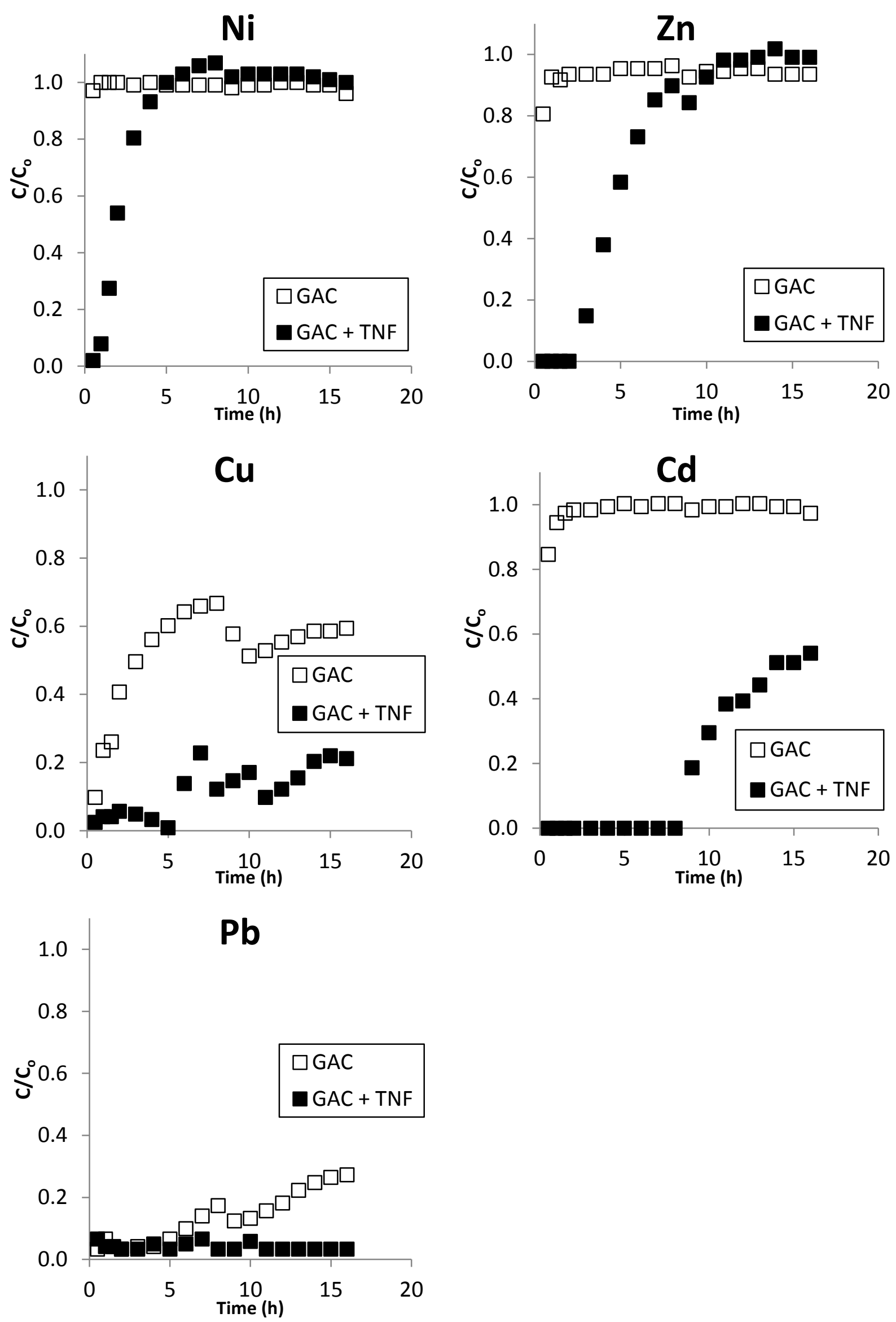

Fig. 7. 


\section{Supplementary Data}

Supplementary Table 1(ST 1). Freundlich isotherm model parameters for the adsorption of heavy metals on TNF from solutions containing mixed metals at an ionic strength of $10^{-3} \mathrm{M} \mathrm{NaNO}_{3}$ for two pHs and coefficients of determination for the Freundlich isotherm fit to data $\left(\mathrm{R}^{2}\right)$.

Freundlich isotherm model

Equation: $q_{e}=K_{F} C_{e}^{1 / n}$

Linear form: $\ln q_{e}=\ln K_{F}+\frac{1}{n} \ln C_{e}$ with $C_{e}=$ the equilibrium concentration of the adsorbate $(\mathrm{mg} / \mathrm{L})$; $q_{e}=$ the amount of adsorbate adsorbed per unit mass of adsorbent (mg/g); $K_{F}$ and $\mathrm{n}=$ Freundlich constants. From the plots of $\ln q_{e}$ vs $\ln C_{e}$ the $K_{F}$ and n were calculated.

Data separated into low (L) and high (H) metal concentrations

\begin{tabular}{|c|c|c|c|c|c|c|c|c|}
\hline \multirow[b]{3}{*}{ Metals } & \multicolumn{4}{|c|}{ Low metal concentration } & \multicolumn{4}{|c|}{ High metal concentration } \\
\hline & \multicolumn{4}{|c|}{$\mathrm{pH} 5.0$} & \multicolumn{4}{|c|}{$\mathrm{pH} 5.0$} \\
\hline & $\begin{array}{c}\mathrm{K}_{\mathrm{F}} \\
(\mathrm{mg} / \mathrm{g}) \\
(\mathrm{L} / \mathrm{mg})^{1 / \mathrm{n}}\end{array}$ & $\mathrm{n}$ & $\mathrm{R}^{2}$ & $\mathrm{~N}$ & $\begin{array}{c}\mathrm{K}_{\mathrm{F}} \\
(\mathrm{mg} / \mathrm{g}) \\
(\mathrm{L} / \mathrm{mg})^{1 / \mathrm{n}}\end{array}$ & $\mathrm{n}$ & $\mathrm{R}^{2}$ & $\mathrm{~N}$ \\
\hline $\mathrm{Ni}$ & 15.9 & -34.0 & 0.1486 & 8 & 4136.9 & -0.4 & 0.8314 & 8 \\
\hline $\mathrm{Zn}$ & 17.6 & 93.5 & 0.0382 & 9 & 915.8 & -0.6 & 0.7715 & 7 \\
\hline $\mathrm{Cd}$ & 27.1 & 13.4 & 0.6574 & 6 & 186.0 & -1.1 & 0.8354 & 5 \\
\hline $\mathrm{Cu}$ & 30.9 & 7.2 & 0.8728 & 6 & 85.4 & -2.6 & 0.7236 & 5 \\
\hline $\mathrm{Pb}$ & - & - & - & - & - & - & - & - \\
\hline \multirow[b]{2}{*}{ Metals } & \multicolumn{4}{|c|}{ pH 6.5} & \multicolumn{4}{|c|}{$\mathrm{pH} 6.5$} \\
\hline & $\begin{array}{c}\mathrm{K}_{\mathrm{F}} \\
(\mathrm{mg} / \mathrm{g}) \\
(\mathrm{L} / \mathrm{mg})^{1 / \mathrm{n}}\end{array}$ & $\mathrm{n}$ & $\mathrm{R}^{2}$ & $\mathrm{~N}$ & $\begin{array}{c}\mathrm{K}_{\mathrm{F}} \\
(\mathrm{mg} / \mathrm{g}) \\
(\mathrm{L} / \mathrm{mg})^{1 / \mathrm{n}}\end{array}$ & $\mathrm{n}$ & $\mathrm{R}^{2}$ & $\mathrm{~N}$ \\
\hline $\mathrm{Ni}$ & 22.2 & -6.5 & 0.7098 & 5 & 477.4 & -0.59 & 0.9140 & 5 \\
\hline $\mathrm{Zn}$ & 22.9 & -41.2 & 0.1577 & 5 & 1649.1 & -0.45 & 0.7575 & 5 \\
\hline $\mathrm{Cd}$ & 34.2 & 8.5 & 0.8806 & 5 & 44.6 & -5.36 & 0.7003 & 5 \\
\hline $\mathrm{Cu}$ & 42.0 & 8.0 & 0.9028 & 5 & 42.0 & -57.80 & 0.0237 & 5 \\
\hline $\mathrm{Pb}$ & - & - & - & - & - & - & - & - \\
\hline
\end{tabular}

N- Number of data points 
Supplementary Table 2(ST 2). The Dubinin-Radushkevick isotherm model parameters for the adsorption of heavy metals $(15 \mathrm{mg} / \mathrm{L})$ on TNF from solutions containing mixed metals at an ionic strength of $10^{-3} \mathrm{M} \mathrm{NaNO}_{3}$ for two pHs and coefficients of determination for the Langmuir isotherm fit to data $\left(\mathrm{R}^{2}\right)$.

\section{The Dubinin-Radushkevick isotherm model}

Equation: $q_{e}=q_{m} \exp \left(-\beta \varepsilon^{2}\right)$

Linear form: $\ln \left(q_{e}\right)=\ln \left(q_{m}\right)-\beta \varepsilon^{2}$

With $q_{e}=$ the amount of heavy metal adsorbed per unit dosage of the adsorbent (mg/g); $q_{m}=$ the monolayer capacity, and $\beta$ is the activity coefficient related to mean sorption energy and $\varepsilon$ is the Palanyi potential described as: $\varepsilon=R \ln \left[1+\left(\frac{1}{C_{e}}\right)\right]$. From the plots of $\ln \left(\mathrm{q}_{\mathrm{e}}\right)$ versus $\varepsilon^{2}$ the values of $\beta$ and $\mathrm{q}_{\mathrm{m}}$ were determined.

$\underline{\text { Data separated into low }(\mathrm{L}) \text { and high }(\mathrm{H}) \text { metal concentrations }}$

\begin{tabular}{|c|c|c|c|c|c|c|c|c|}
\hline \multirow[b]{3}{*}{ Metals } & \multirow{2}{*}{\multicolumn{4}{|c|}{$\begin{array}{c}\text { Low metal concentration } \\
\mathrm{pH} 5.0 \\
\end{array}$}} & \multirow{2}{*}{\multicolumn{4}{|c|}{$\frac{\text { High metal concentration }}{\mathrm{pH} 5.0}$}} \\
\hline & & & & & & & & \\
\hline & $\begin{array}{c}\mathrm{q}_{\mathrm{m}} \\
(\mathrm{mg} / \mathrm{g})\end{array}$ & $\begin{array}{c}\beta \\
\left(\mathrm{mol}^{2} / \mathrm{kJ}^{2}\right)\end{array}$ & $\mathrm{R}^{2}$ & $\mathrm{~N}$ & $\begin{array}{c}\mathrm{q}_{\mathrm{m}} \\
(\mathrm{mg} / \mathrm{g})\end{array}$ & $\begin{array}{c}\beta \\
\left(\mathrm{mol}^{2} / \mathrm{kJ}^{2}\right) \\
\end{array}$ & $\mathrm{R}^{2}$ & $\mathrm{~N}$ \\
\hline $\mathrm{Ni}$ & 2.2 & $-3 \times 10^{-5}$ & 0.7996 & 7 & 15.8 & $-4 \times 10^{-10}$ & 0.0018 & 9 \\
\hline $\mathrm{Zn}$ & 4.3 & $-2 \times 10^{-5}$ & 0.7285 & 8 & 18.4 & $3 \times 10^{-9}$ & 0.2651 & 8 \\
\hline $\mathrm{Cd}$ & 15.6 & $-8 \times 10^{-6}$ & 0.7766 & 5 & 30.8 & $5 \times 10^{-8}$ & 0.9117 & 6 \\
\hline $\mathrm{Cu}$ & 28.8 & $-3 \times 10^{-6}$ & 0.6427 & 5 & 38.0 & $7 \times 10^{-8}$ & 0.9436 & 6 \\
\hline $\mathrm{Pb}$ & - & - & - & - & - & - & - & - \\
\hline \multirow[b]{2}{*}{ Metals } & \multicolumn{4}{|c|}{ pH 6.5} & \multicolumn{4}{|c|}{$\mathrm{pH} 6.5$} \\
\hline & $\begin{array}{c}\mathrm{q}_{\mathrm{m}} \\
(\mathrm{mg} / \mathrm{g})\end{array}$ & $\begin{array}{c}\beta \\
\left(\mathrm{mol}^{2} / \mathrm{kJ}^{2}\right)\end{array}$ & $\mathrm{R}^{2}$ & $\mathrm{~N}$ & $\begin{array}{c}\mathrm{q}_{\mathrm{m}} \\
(\mathrm{mg} / \mathrm{g})\end{array}$ & $\begin{array}{c}\beta \\
\left(\mathrm{mol}^{2} / \mathrm{kJ}^{2}\right)\end{array}$ & $\mathrm{R}^{2}$ & $\mathrm{~N}$ \\
\hline $\mathrm{Ni}$ & 4.0 & $-5 \times 10^{-8}$ & 0.3893 & 5 & 17.4 & $-2 \times 10^{-5}$ & 0.9154 & 5 \\
\hline $\mathrm{Zn}$ & 3.4 & $-2 \times 10^{-5}$ & 0.7217 & 5 & 22.5 & $-3 \times 10^{-9}$ & 0.0253 & 5 \\
\hline Cd & 29.7 & $-3 \times 10^{-7}$ & 0.4451 & 5 & 35.1 & $8 \times 10^{-9}$ & 0.9365 & 5 \\
\hline $\mathrm{Cu}$ & 41.1 & $2 \times 10^{-8}$ & 0.0161 & 5 & 39.3 & $5 \times 10^{-9}$ & 0.9313 & 5 \\
\hline $\mathrm{Pb}$ & - & - & - & - & - & - & - & - \\
\hline
\end{tabular}

$\mathrm{N}$ - Number of data points 
Supplementary Figure 1 (SF 1). SEM images of TNF (magnifications 5,000X (left), 30,000X (middle) and 33000X (right)).

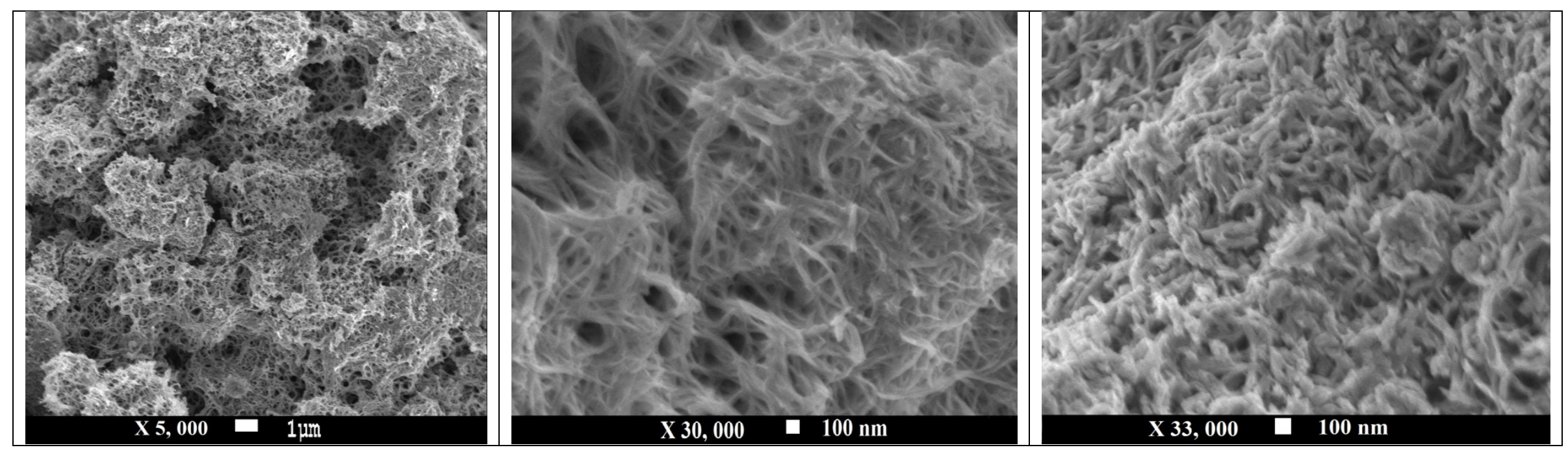


Supplementary Figure 2 (SF 2). Langmuir plots for metals adsorption on TNF from single metal solutions at different pHs.
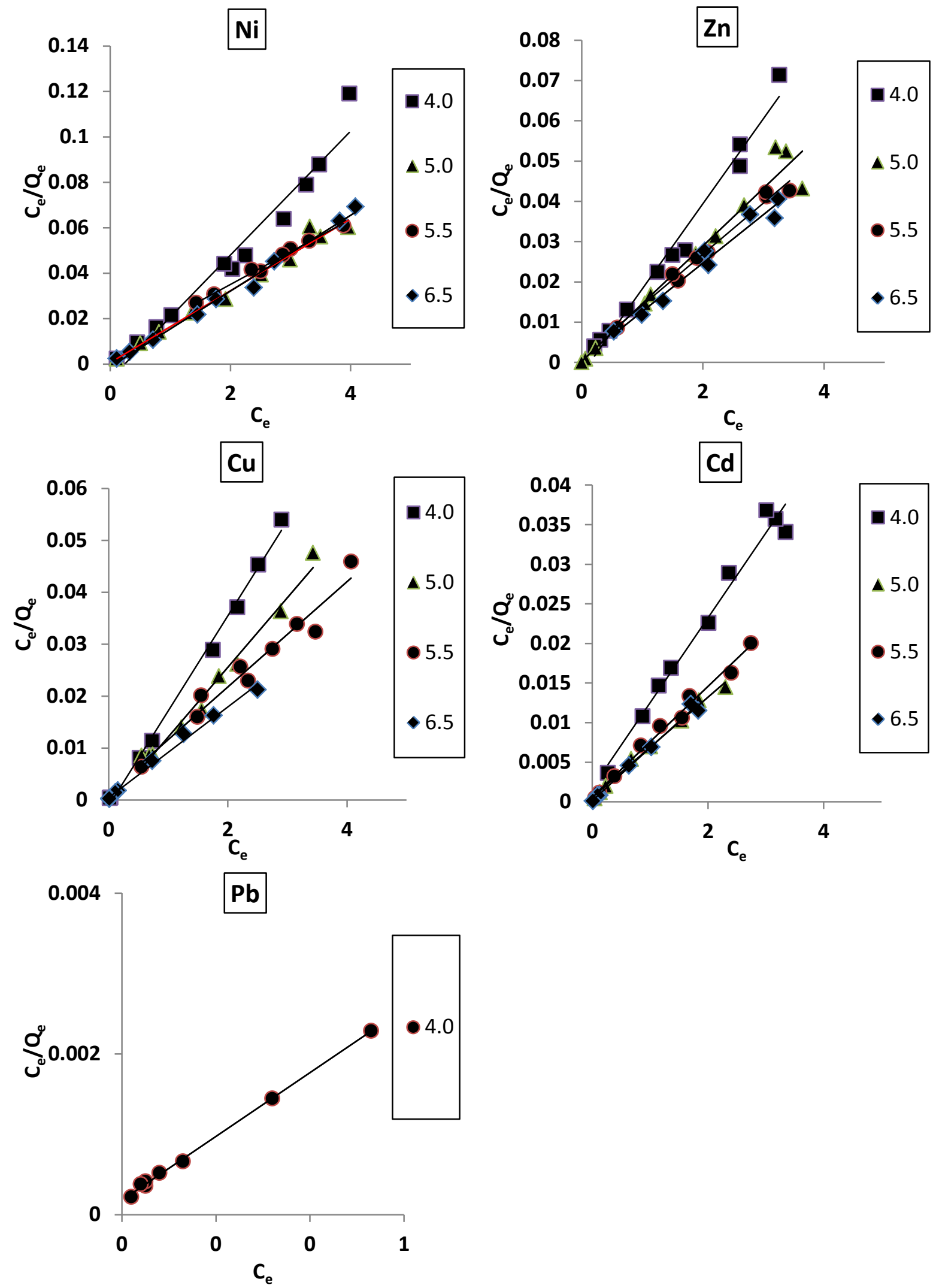
Supplementary Figure 3 (SF 3). Langmuir plots for adsorption of metals on TNF from solutions containing mixed metals at low and high metal concentrations at $\mathrm{pH} 5$.
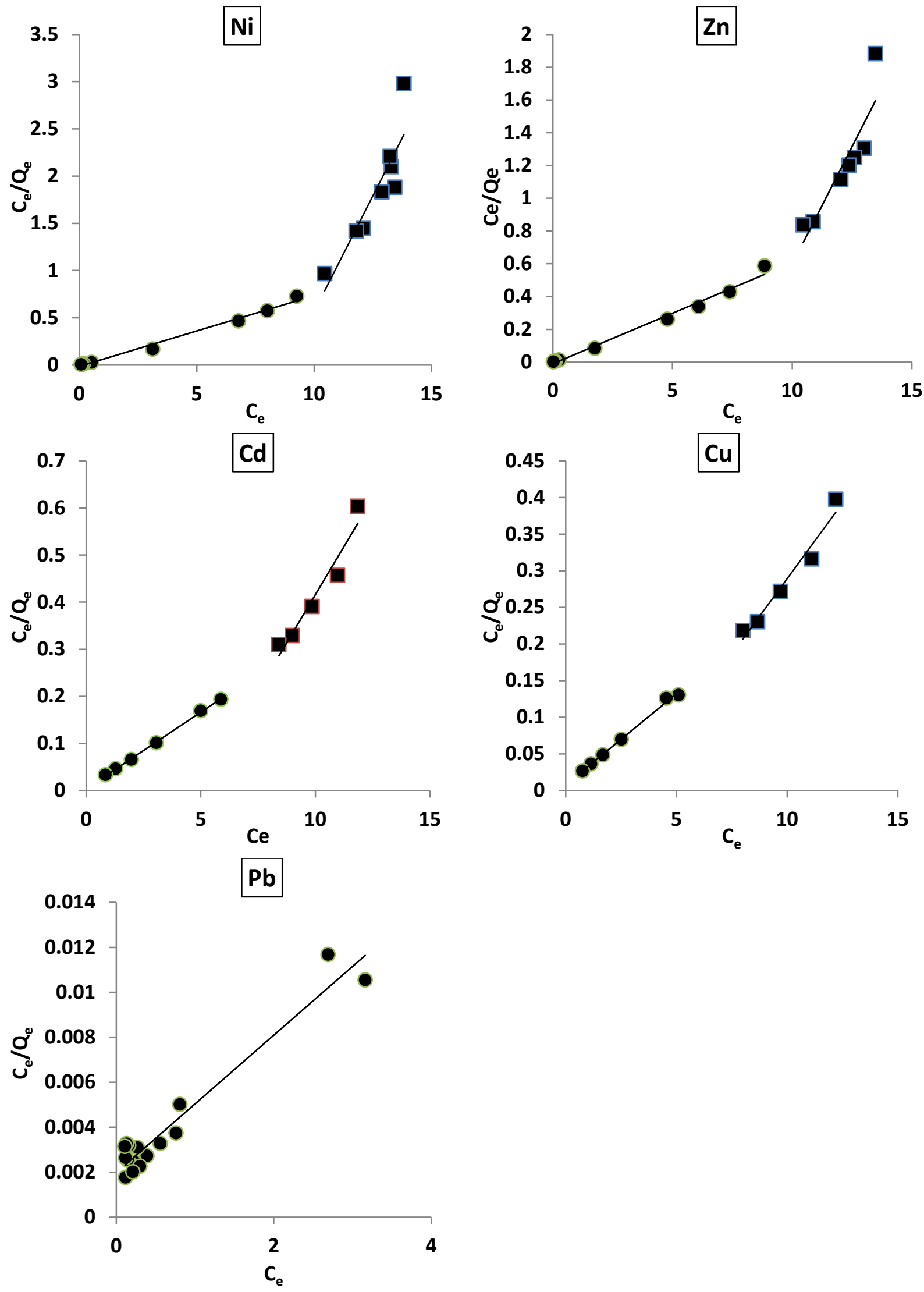
Supplementary Figure 4 (SF 4). Langmuir plots for adsorption of metals on TNF from solutions containing mixed metals at low and high metal concentrations at $\mathrm{pH} 6.5$.
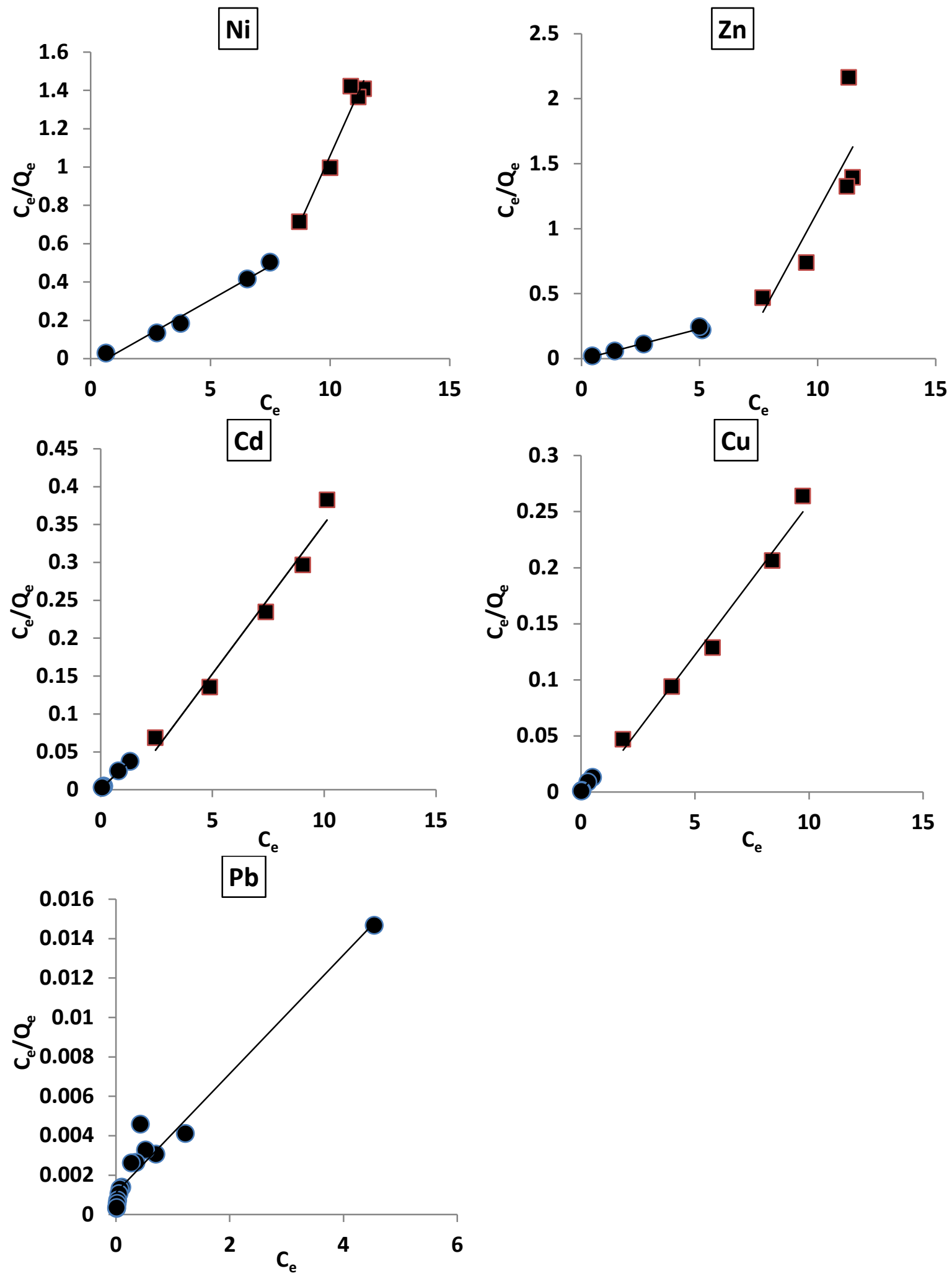
Supplementary Figure 5 (SF 5). Langmuir plots for adsorption of metals on TNF from solutions containing mixed metals at different pHs (not divided into two regions).
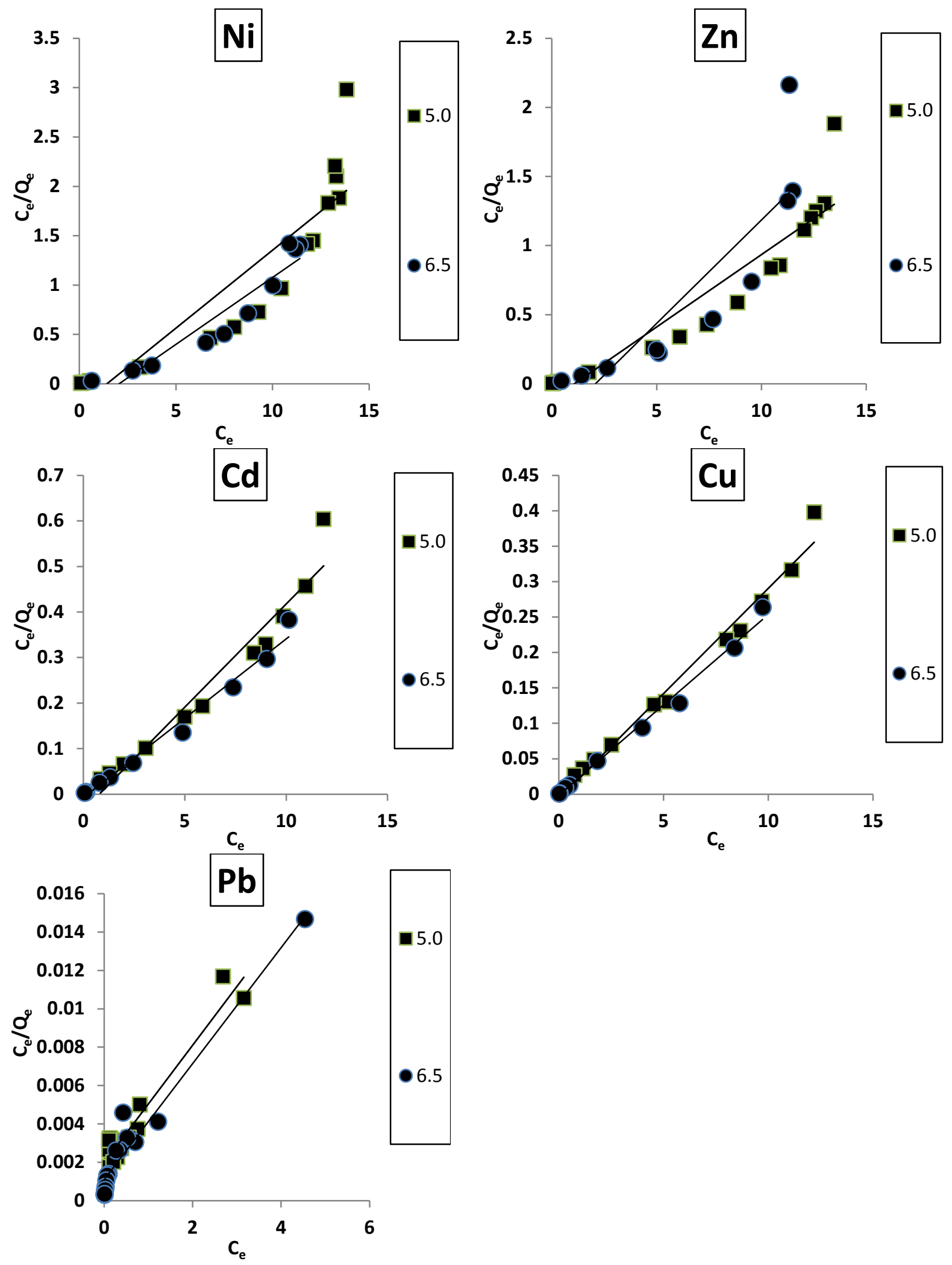